\title{
Dynamically Downscaled Projections of Lake-Effect Snow in the Great Lakes Basin*,+
}

\author{
Michael Notaro, Val Bennington, and Steve Vavrus \\ Nelson Institute Center for Climatic Research, University of Wisconsin-Madison, Madison, Wisconsin
}

(Manuscript received 30 June 2014, in final form 17 October 2014)

\begin{abstract}
Projected changes in lake-effect snowfall by the mid- and late twenty-first century are explored for the Laurentian Great Lakes basin. Simulations from two state-of-the-art global climate models within phase 5 of the Coupled Model Intercomparison Project (CMIP5) are dynamically downscaled according to the representative concentration pathway 8.5 (RCP8.5). The downscaling is performed using the Abdus Salam International Centre for Theoretical Physics (ICTP) Regional Climate Model version 4 (RegCM4) with 25-km grid spacing, interactively coupled to a one-dimensional lake model. Both downscaled models produce atmospheric warming and increased cold-season precipitation. The Great Lakes' ice cover is projected to dramatically decline and, by the end of the century, become confined to the northern shallow lakeshores during mid-to-late winter. Projected reductions in ice cover and greater dynamically induced wind fetch lead to enhanced lake evaporation and resulting total lake-effect precipitation, although with increased rainfall at the expense of snowfall. A general reduction in the frequency of heavy lake-effect snowstorms is simulated during the twenty-first century, except with increases around Lake Superior by the midcentury when local air temperatures still remain low enough for wintertime precipitation to largely fall in the form of snow. Despite the significant progress made here in elucidating the potential future changes in lake-effect snowstorms across the Great Lakes basin, further research is still needed to downscale a larger ensemble of CMIP5 model simulations, ideally using a higher-resolution, nonhydrostatic regional climate model coupled to a threedimensional lake model.
\end{abstract}

\section{Introduction}

Historical trends in lake-effect snowfall across the Great Lakes basin have been the focus of numerous observational analyses. Lake-effect snowstorms have attracted broad research attention given their dramatic socioeconomic impacts on agriculture, transportation, commerce, infrastructures, water supply, hydroelectric generation, and recreation (Changnon 1979; Norton and Bolsenga 1993; Schmidlin 1993; Kunkel et al. 2002). Burnett et al. (2003) found a significant positive snowfall

\footnotetext{
* Nelson Institute Center for Climatic Research Contribution No. 1208.

${ }^{+}$Supplemental information related to this paper is available at the Journals Online website: http://dx.doi.org/10.1175/JCLI-D-1400467.s1.
}

Corresponding author address: Michael Notaro, Nelson Institute Center for Climatic Research, University of Wisconsin-Madison, 1225 West Dayton Street, Madison, WI 53706.

E-mail: mnotaro@wisc.edu trend among lake-effect sites in the Great Lakes basin during 1931-2001, but no trend among non-lake-effect sites, and hypothesized that the positive trend was associated with warming lakes (Assel and Robertson 1995) and declining lake ice cover. Ellis and Johnson (2004) attributed the positive snowfall trends in the lee of Lakes Ontario and Erie to a shift toward more snow events and less rain events, decline in midwinter rainfall, increase in snowfall event intensity, and lower snow densities. According to Kunkel et al. (2009), significant positive snowfall trends occurred in the snowbelt zones of Lakes Superior and Michigan since the turn of the twentieth century in response to warming waters, declining ice cover, and enhanced evaporation. Bard and Kristovich (2012) suggested that, after about 1980, the positive trend in lake-contributed snowfall reversed sign to the east and south of Lake Michigan.

Increasing attention is being paid to extreme weather events, because of their acute societal impacts, improved modeling capabilities, and concern over anthropogenic climate change. The Fifth Assessment Report of the Intergovernmental Panel on Climate Change (IPCC) 
summarized the existing research on extreme events, including heat and cold waves, droughts, floods, and extratropical wind storms. One notable phenomenon missing from this list is heavy lake-effect snowstorms, to which current and past IPCC assessment reports and U.S. National Climate Assessments give minimal coverage. It remains uncertain how the frequency of these cold season extremes will change during the twenty-first century. On one hand, the observed positive trend in lake-effect snowfall in the Great Lakes basin may persist, as lake ice cover continues to decline in response to warming and lake evaporation increases, providing moisture to lakeeffect events. However, Kunkel et al. (2002) found an inverse relationship between winter air temperatures and the number of heavy lake-effect snow days, thereby complicating the reliability of this hypothesis. On the other hand, the positive trend may eventually reverse as extreme cold air outbreaks, which are key triggers of lakeeffect snowstorms, become less common in response to anthropogenic climate change. Extreme North American cold-air outbreaks are projected by Vavrus et al. (2006) to decline in frequency by $74 \%$ and $87 \%$ by the mid- and late twenty-first century, respectively.

Prior investigations of projected lake-effect snowfall, both in terms of mean and extremes, in the Great Lakes basin for the twenty-first century have been sparse (Cohen and Allsopp 1988; Kunkel et al. 2002; Gula and Peltier 2012). Focusing on the Lake Erie snowbelt, Kunkel et al. (2002) assessed transient twenty-firstcentury model output from two coarse GCMs, one of which represented the Great Lakes by three water grid cells while the other did not contain the lakes. GCMs are generally insufficient tools for simulating lake-effect snowstorms because of coarse resolution, poor representation of topography, difficulty in simulating mesoscale circulations or localized convection, and the absence of or underrepresentation of the Great Lakes. In recognition of this limitation, Kunkel et al. (2002) instead assessed projected changes in the frequency of heavy lake-effect snowstorms by the late twenty-first century by considering changes in favorable large-scale meteorological fields. The surface conditions favorable for such storms decreased in frequency by $50 \%$ and $90 \%$ in the two GCMs, largely due to projected warming.

For investigating projected changes in lake-effect snow, regional climate models (RCMs) hold several critical advantages over GCMs, with potential added value (Bader et al. 2007; Feser et al. 2011; Kanamitsu and DeHaan 2011). RCMs can accurately represent the relationship between the large-scale circulation and regional climate, while accounting for topographic influences from mountains, lakes, and coastlines. An $\mathrm{RCM}$ can potentially represent the Great Lakes with hundreds of grid cells and, if interactively coupled to a lake module, can simulate lake ice's seasonal evolution. The fine resolution of an RCM and detailed parameterizations can capture synoptic and mesoscale features, such as lake-effect snow bands (Ballentine et al. 1998), strong upward motions (Jones et al. 1995), convection (Anderson et al. 2007), and nocturnal jets (Byerle and Paegle 2003). Previous studies have shown that models with 20-30-km grid spacing can successfully simulate lake-effect snow (Hjelmfelt and Braham 1983; Warner and Seaman 1990; Sousounis and Fritsch 1994; Ballentine et al. 1998) at the meso- $\beta$ scale (Orlanski 1975), including type-I wind-parallel snow bands (Hill 1971; Niziol et al. 1995). The high spatial resolution of an RCM represents complex variations in land cover and topography (Leung and Wigmosta 1999; Mearns 2003; Mearns et al. 2003; Hay et al. 2006). While a higherresolution model may not improve the simulated largescale circulation pattern, it will likely simulate more accurate precipitation variability and intensity (Roads et al. 2003; Mo et al. 2005).

Rather than inferring projected changes in lake-effect snowfall through large-scale meteorological criteria in coarse GCM output, Gula and Peltier (2012) explicitly simulated lake-effect snowfall in the Great Lakes basin using an RCM with 10-km grid spacing, the Weather Research and Forecasting Model (WRF). They dynamically downscaled simulations from the National Center for Atmospheric Research (NCAR) Community Climate System Model version 3 (CCSM3) within phase 3 of the Coupled Model Intercomparison Project (CMIP3) using WRF for the SRES A2 emission scenario for 1979-2001 and 2050-60. Given that WRF had not yet been interactively coupled to a lake model, they forced the Freshwater Lake Model (FLake) offline with CCSM3 atmospheric fields to derive lake temperature and ice cover boundary conditions for WRF; however, this approach neglects important lake-atmosphere feedbacks, which can influence regional climate projections. Gula and Peltier (2012) simulated a reduction in the duration of lake ice cover by 25 days for Lake Erie and up to 50 days for Lake Superior by the mid-twentyfirst century in response to increases of $2^{\circ}-4^{\circ} \mathrm{C}$ in surface air temperature during autumn and spring. This earlier ice breakup favored earlier lake stratification and thus rapid lake surface warming during summer, consistent with historical trends (Austin and Colman 2007). Despite small $(5 \%-20 \%)$ projected reductions in annual (particularly from autumn to early winter) snowfall downwind of the Great Lakes by the mid-twenty-first century, WRF produces a midwinter increase in lakeatmosphere temperature gradient, sensible and latent heat fluxes, and atmospheric boundary layer depth, 
which support greater lake-effect snowfall downwind of Lake Superior (approximately $+20 \%$ in February).

In the current study, high-resolution climate projections are generated for the mid- and late twenty-first century for the Great Lakes basin by dynamically downscaling simulations from two GCMs within phase 5 of the Coupled Model Intercomparison Project (CMIP5; Taylor et al. 2012) using a 25-km RCM interactively coupled to a lake model. Analyses primarily focus on within-basin projected changes in both the mean cold season climate, focusing on air and lake temperatures, precipitation, lake ice, turbulent fluxes, and snowfall, and on climatic extremes, namely lake-effect snowstorm frequency. The data and methods are presented in section 2 , results are described in section 3 , and discussion and conclusions are provided in section 4 .

\section{Data and methods}

\section{a. Model description}

Climate change projections are developed using the Abdus Salam International Centre for Theoretical Physics (ICTP) Regional Climate Model version 4 (RegCM4; Elguindi et al. 2011; Giorgi et al. 2012) and analyzed for the Great Lakes basin. Its dynamical core is based on the fifth-generation Pennsylvania State University (PSU)National Center for Atmospheric Research (NCAR) Mesoscale Model (MM5; Grell et al. 1994). RegCM4 is a compressible, finite-difference model using vertical sigma coordinates and constrained to hydrostatic balance. In this study, a horizontal grid spacing of 25-km (Fig. 1) and 28 vertical sigma levels (12 levels below $850 \mathrm{hPa}$ ) are applied. Resolvable-scale precipitation and nonconvective clouds are treated by a subgrid explicit moisture (SUBEX) scheme (Pal et al. 2000). The Grell (1993) cumulus convection scheme is applied to address smallerscale precipitation, given its superior performance to other schemes in the study region (Notaro et al. 2013b), in conjunction with the Fritsch and Chappell (1980) cumulus closure scheme. The Biosphere-Atmosphere Transfer Scheme (BATS; Dickinson et al. 1986, 1993) serves as the land surface component for the present study, with three soil layers and 20 land cover classes.

In this study, RegCM4 is interactively coupled to a onedimensional, energy-balance lake model (Hostetler and Bartlein 1990) with 1-m vertical resolution, which accounts for vertical heat transfer within a lake column by eddy diffusion and convective mixing/overturning. The lake ice submodel (Patterson and Hamblin 1988; Hostetler 1991) treats snow on ice but does not permit fractional ice cover within a grid box, so every lake cell is either completely ice covered or ice free at any moment. The ice cover scheme represents heat and moisture exchanges between open water and ice surfaces and the atmosphere and computes the surface energy of lake ice and overlying snow. The lake model does not consider advective, horizontal heat transfer between neighboring lake points or vertical heat transfer between the lake bottom and lake water. Lake sensible and latent heat fluxes are computed using bulk aerodynamic formulas (Dickinson et al. 1993). Spatially explicit lake depths are assigned using bathymetry data. At $25-\mathrm{km}$ grid spacing, the Great Lakes are represented by 431 grid cells (Fig. 1). Following Bennington et al. (2014) and Notaro et al. (2013b), several corrections are applied to the lake model, related to calculation of shortwave extinction coefficients, lake heating by shortwave radiation, generation of local mixing around unstable lake layers, intensity of eddy diffusion within deep lake points, and energy conservation within ice melting and growth computations.

The performance of RegCM4 and its lake model has been extensively evaluated for the Great Lakes basin (Hostetler et al. 1993; Bates et al. 1995; Martynov et al. 2010; Holman et al. 2012; Notaro et al. 2013a,b; Bennington et al. 2014); as such, the current study includes a less detailed model evaluation. Notaro et al. (2013b) assessed RegCM4's performance in a historical simulation of 1976-2002, using lateral boundary conditions (LBCs) from the National Centers for Environmental Prediction (NCEP)-NCAR reanalysis (Kalnay et al. 1996) and the Met Office Global Sea Ice and Sea Surface Temperature (GISST) dataset (Rayner et al. 1996). The model generally reproduces the seasonal cycle of lake surface temperatures (LSTs) compared to buoy and remote sensing data, although with a summertime warm bias and anomalously early onset of lake stratification (Bennington et al. 2014). RegCM4 produces a fair representation of the spatial distribution and seasonal evolution of Great Lakes' ice cover, although the absence of horizontal mixing and ice movement in the lake model causes an excessive and overly persistent ice cover (Notaro et al. 2013b). The model simulates a reasonable spatial pattern of annual snowfall across the Midwest, northeastern United States, and Great Lakes basin, including the major lake-effect snow regions, which are characterized by at least $250 \mathrm{~cm}$ of annual snowfall (Notaro et al. 2013b). Mean snowfall consistently peaks in January downwind of the lakes in both the model and observations, while extensive ice cover in February reduces simulated and observed lake-effect snowfall (Notaro et al. 2013b). RegCM4 can capture the broad snowfall patterns of observed lake-effect snowstorm case studies (Vavrus et al. 2013). Within the 1976-2002 simulation, RegCM4 accurately simulates the interannual fluctuations and longterm trends in basinwide air temperatures, lake ice cover, and lake-effect snowfall (Notaro et al. 2013b). 


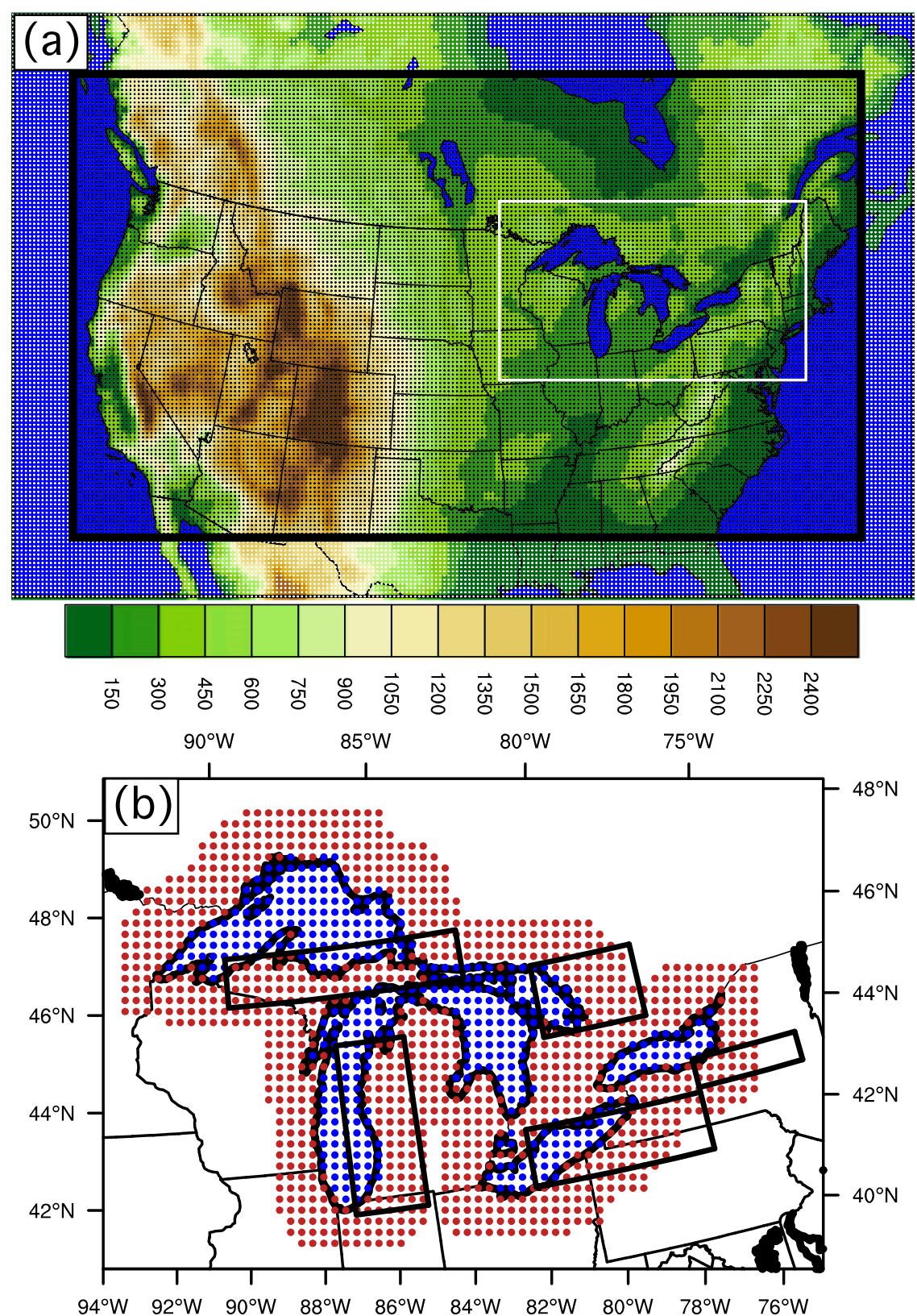

FIG. 1. (a) Model domain with elevation (shading; $m$ ). The thick black rectangle indicates the buffer zone. The white rectangle represents the broader Great Lakes region (used for area averages in Figs. 2 and 3). (b) Zoomed-in map with blue dots for lake grid cells, brown dots for terrestrial grid cells within the lake-effect zone of $100 \mathrm{~km}$ from lakeshores (used in Fig. 16), and rectangles identifying the areas downwind of each lake (used in Figs. 12 and 15). The rectangles include $46^{\circ}-47^{\circ} \mathrm{N}, 83^{\circ}-90^{\circ} \mathrm{W}$ for Lake Superior; $44.5^{\circ}-46^{\circ} \mathrm{N}, 78^{\circ}-81^{\circ} \mathrm{W}$ for Lake Huron; $42.8^{\circ}$ $43.4^{\circ} \mathrm{N}, 74^{\circ}-77^{\circ} \mathrm{W}$ for Lake Ontario; $41.5^{\circ}-45^{\circ} \mathrm{N}, 85^{\circ}-87^{\circ} \mathrm{W}$ for Lake Michigan; and $41.5^{\circ}-$ $42.7^{\circ} \mathrm{N}, 77^{\circ}-82^{\circ} \mathrm{W}$ for Lake Erie.

\section{b. Experiment design}

The RegCM4 simulations apply $25-\mathrm{km}$ grid spacing for a domain of $217 \times 141$ grid cells, encompassing most of the contiguous United States and southern Canada
(Fig. 1a). Using a linear relaxation scheme, LBCs are provided to a 15 gridcell buffer zone, surrounding the inner domain. The NCEP-RegCM4 simulation is produced for 1976-2010, using the NCEP-NCAR reanalysis and GISST dataset for LBCs, of which 1980-99 
is analyzed. The MIROC5-RegCM4 and CNRMRegCM4 simulations are developed for the late twentieth (1970-99), mid-twenty-first (2030-59), and late twenty-first (2070-99) centuries, of which 1980-99, 2040-59, and 2080-99 are analyzed; for these runs, RegCM4 dynamically downscales simulations from two CMIP5 GCMs, namely the Model for Interdisciplinary Research on Climate version 5 (MIROC5) and the Centre National de Recherches Météorologiques Coupled Global Climate Model version 5 (CNRM-CM5). The criteria for selecting these two models are outlined in section 3a. The statistical significance of projected changes is assessed using the Student's $t$ test.

The Great Lakes are crudely represented by these GCMs in their CMIP5 simulations (see Fig. S1 in the supplemental material). In MIROC5 (Watanabe et al. 2010), only 12 horizontal grid cells, located within the actual Great Lakes basin, are assigned at least $50 \%$ water. MIROC5 applies the Matsiro land surface model (Takata et al. 2003), which includes a simple lake submodel with one surface layer and four subsurface layers. In CNRM-CM5, the Great Lakes are represented by 10 grid cells, with at least 50\% water (Voldoire et al. 2013). Lakes are included within CNRM-CM5's Surface Externalisée (SURFEX) interface, in which the LSTs are updated daily through extrapolation from the nearest ocean grid cell. Despite the limitations of a onedimensional (1D) lake model, the high-resolution coupled RegCM4-1D lake model is a clear advance over the Great Lakes' depiction in either MIROC5 or CNRMCM5 in terms of horizontal and vertical resolution and represented processes.

Simulated hourly snowfall amounts are computed based on simulated air temperature $T_{a}$ and water equivalent of new snowfall $P_{n}(\mathrm{~mm})$ (Anderson 1976, 2006; Notaro et al. 2013b). Precipitation is assumed to occur as snowfall when $T_{a}$ is less than $0^{\circ} \mathrm{C}$. Here, $\rho_{n}$ and $\rho_{w}$ are the density of new snow and water, respectively. New snow depth $H_{n}(\mathrm{~cm})$ is computed by

$$
H_{n}=0.1 P_{n}\left(\rho_{w} / \rho_{n}\right) \text {. }
$$

The new snow density is set to $0.05 \mathrm{~g} \mathrm{~cm}^{-3}$ if $T_{a}$ is less than $-15^{\circ} \mathrm{C}$ or otherwise computed as

$$
\rho_{n}=0.05+0.0017\left(T_{a}+15\right)^{1.5} \text {. }
$$

\section{c. Criteria for identifying simulated heavy lake-effect snow days}

Simulated heavy lake-effect snow days are identified in the RCM output following the approach of Notaro et al. (2013b), who introduced a regionally applicable definition for identifying heavy lake-effect snowstorms in the Great Lakes basin from RCM output, based on fetch, lake ice coverage, snowfall amount, local snowfall enhancement, and proximity to a lake. Here, "heavy" is defined relative to typical simulated daily snowfall totals in the basin. For each grid cell in the basin and each day of RCM output, the following criteria are applied to determine if a heavy lake-effect, or lake-enhanced (Eichenlaub 1979), snowstorm occurred.

1) Location: The grid cell must be located over land and within $100 \mathrm{~km}$ of one of the Great Lakes' shorelines (Fig. 1b), given that the heaviest snowfall amounts typically occur within $100 \mathrm{~km}$ of a lake (Dewey 1979; Eichenlaub 1979).

2) Fetch: For at least $6 \mathrm{~h}$, the mean $10-\mathrm{m}$ wind direction must be off one of the lakes, allowing for sufficient fetch. Kunkel et al. (2002) recognized the importance of wind direction for lake-effect snowstorms downwind of Lake Erie.

3) Lake ice: The ice cover fraction on the lake, off which the wind is flowing, must be less than $70 \%$, given that Gerbush et al. (2008) found that observed sensible heat fluxes dramatically decline nonlinearly for percent ice covers beyond $70 \%$.

4) Snowfall amount: The local daily snowfall must be at least $10 \mathrm{~cm}$, following the criterion applied by Liu and Moore (2004) for lake-effect snowstorms in southern Ontario.

5) Snowfall enhancement: Following the general approach of Kunkel et al. (2002), the local, near-lake daily snowfall must exceed the mean nonlocal, continental snowfall, far from the lake, by at least $4 \mathrm{~cm}$. For each grid cell under consideration, a moving window of 20 grid cells $(500 \mathrm{~km})$ in each direction is assigned and the mean snowfall within this box is computed for all grid cells beyond the 100-km lakeeffect zone. This value represents the nonlocal, continental snowfall, not attributed to lake-effect snowfall.

\section{d. Additional datasets}

Projected changes in air temperature and precipitation over land in the Great Lakes basin are assessed among $33 \mathrm{GCMs}$ from their historical twentieth-century runs and transient twenty-first-century runs within CMIP5 according to representative concentration pathway 8.5 (RCP8.5), focusing on three time periods: 1980-99, 2040-59, and 2080-99. Only one ensemble member is considered per model and per scenario. A high-emission "business as usual" scenario is selected to amplify the greenhouse gas-related climate change signal in comparison to natural climate variability, particularly since 
only two GCMs are downscaled. Simulated near-surface air temperature and precipitation are evaluated against the $0.5^{\circ} \times 0.5^{\circ}$ University of Delaware gridded observations (Willmott and Matsuura 2000) for 1980-99. In addition to this unadjusted precipitation dataset, an adjusted version is obtained which addresses wetting losses and wind-induced precipitation undercatchment at gauges (Adam and Lettenmaier 2003; Adam et al. 2006). Simulated precipitation should ideally fit within the range of the unadjusted and adjusted datasets, recognizing observational uncertainty. Simulated LSTs are assessed against the National Oceanic and Atmospheric Administration (NOAA) Great Lakes Surface Environmental Analysis (GLSEA) dataset for 1980-99, from the Advanced Very High Resolution Radiometer (Schwab et al. 1992). The simulated seasonal cycle of lake temperature vertical profiles is evaluated against NOAA's Great Lakes Environmental Research Laboratory (GLERL) Lake Michigan vertical temperature dataset from Li et al. (2009), which contains temperature readings from the top $50 \mathrm{~m}$ of central Lake Michigan $\left(42.67^{\circ} \mathrm{N}, 87.08^{\circ} \mathrm{W}\right)$ for 1995-2010. NOAA’s Great Lakes Ice Atlas (Assel 2003), containing daily percent ice cover for 1980-99, is applied to evaluate the simulated spatial pattern and seasonal cycle of lake ice cover. To compute the percent ice cover on each lake using RCM output, a grid cell on a given day is assigned $100 \%$ ice cover if its ice thickness is at least $2 \mathrm{~cm}$, or $0 \%$ otherwise. Using the same station data as Notaro et al. (2013b), simulated snowfall is compared against observations for 1980-99 at 2880 stations from the high-resolution U.S. Cooperative Observer Dataset, downloaded from the National Climatic Data Center (NCDC) website, and Environment Canada's online climate archive.

\section{Results}

\section{a. CMIP5 projections for winter-spring across the Great Lakes region}

Despite a broad range in the magnitude of projected changes, all of the analyzed 33 CMIP5 GCMs simulate increases in near-surface air temperature and precipitation during the winter-to-spring period of December-May (Great Lakes' ice season; Assel 1990; Notaro et al. 2013b) across the broader Great Lakes region (defined as $40^{\circ}-50^{\circ} \mathrm{N}, 70^{\circ}-95^{\circ} \mathrm{W}$ ) by both the midtwenty-first and late twenty-first century (Fig. 2). The projected warming by the mid-twenty-first century has a mean of $+3.1^{\circ} \mathrm{C}$ and an across-model range from $+1.2^{\circ}$ to $+5.3^{\circ} \mathrm{C}$, while the projected change in precipitation has a mean of $+0.30 \mathrm{~mm} \mathrm{day}^{-1}$ and a range from +0.07 to $+0.54 \mathrm{~mm} \mathrm{day}^{-1}$. The mid-twenty-first-century projections include greater warming in MIROC5

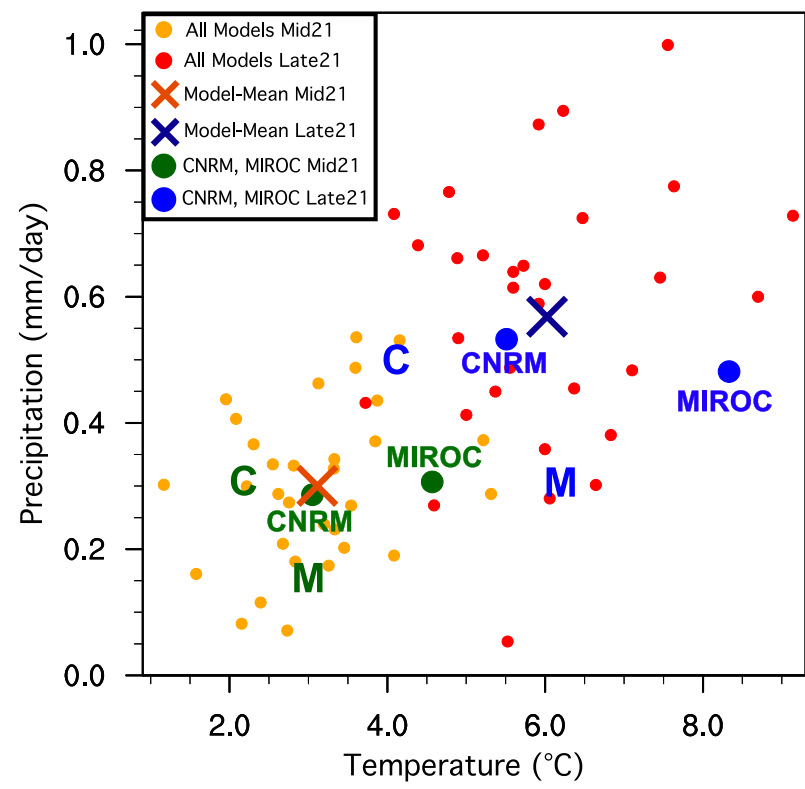

FIG. 2. Projected changes in December-May 2-m air temperature $\left({ }^{\circ} \mathrm{C}\right)$ and precipitation $\left(\mathrm{mm} \mathrm{day}^{-1}\right)$ across the broader Great Lakes region $\left(40^{\circ}-50^{\circ} \mathrm{N}, 95^{\circ}-70^{\circ} \mathrm{W}\right.$, land only), computed as the difference between either 2040-59 or 2080-99 and 1980-99. Each dot represents one of 33 CMIP5 GCMs for mid-twenty-first (orange) or late-twenty-first (red) century projections. For both periods, model-mean projections are shown with crosses. Projections from CNRM and MIROC5 are identified with large green and blue dots for the mid-twenty-first and late twenty-first centuries, respectively. RCM-based projections for the mid-twenty-first (green) and late twenty-first (blue) century are indicated by " $\mathrm{C}$ " for CNRM-RegCM4 and "M" for MIROC5-RegCM4.

$\left(+4.6^{\circ} \mathrm{C}\right)$ than CNRM-CM5 $\left(+3.1^{\circ} \mathrm{C}\right)$ but nearly identical precipitation projections, namely $+0.31 \mathrm{~mm} \mathrm{day}^{-1}$ in MIROC5 and $+0.29 \mathrm{~mm} \mathrm{day}^{-1}$ in CNRM-CM5. By the late twenty-first century, the projected warming among the 33 models has a mean of $+6.0^{\circ} \mathrm{C}$ and an across-model range from $+3.7^{\circ}$ to $+9.1^{\circ} \mathrm{C}$, while the projected change in precipitation has a mean of $+0.57 \mathrm{~mm} \mathrm{day}^{-1}$ and a range from +0.05 to $+1.00 \mathrm{~mm} \mathrm{day}^{-1}$. Again, MIROC5 produces a greater warming $\left(+8.3^{\circ} \mathrm{C}\right)$ than does CNRM-CM $5\left(+5.5^{\circ} \mathrm{C}\right)$ by the late twenty-first century but with nearly identical precipitation projections (MIROC5: $+0.48 \mathrm{~mm}$ day $^{-1}$ and CNRM-CM5: $\left.+0.53 \mathrm{~mm} \mathrm{day}^{-1}\right)$. A seasonal analysis of CMIP5 model-mean projections across the Great Lakes basin for the late twenty-first century indicates peak warming in winter [December-February (DJF): $\left.+7.0^{\circ} \mathrm{C}\right]$ and an increase in annual precipitation that is primarily attributed to spring [March-May (MAM): $+0.61 \mathrm{~mm} \mathrm{day}^{-1}$ ] and winter (DJF: $+0.53 \mathrm{~mm} \mathrm{day}^{-1}$ ). The projected warming is largest in winter for CNRMCM5 and spring for MIROC5, while both produce the greatest increase in precipitation during spring. The 

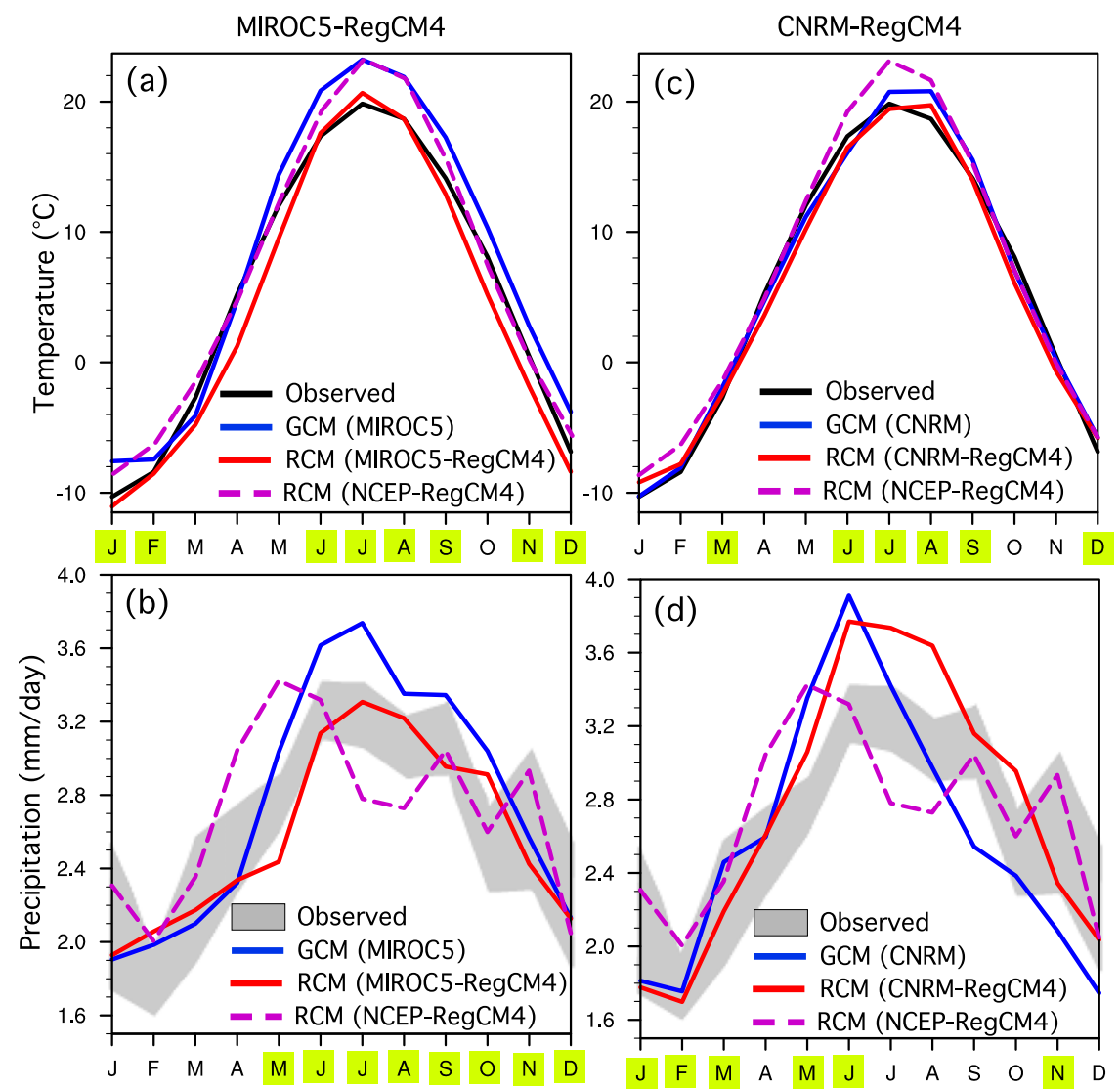

Fig. 3. (a),(c) Mean seasonal cycle of 2-m air temperature $\left({ }^{\circ} \mathrm{C}\right)$ across the broader Great Lakes region $\left(40^{\circ}-50^{\circ} \mathrm{N}, 95^{\circ}-70^{\circ} \mathrm{W}\right.$, land only) for $1980-99$ from University of Delaware observations (black), GCMs (blue: MIROC5, CNRM-CM5), and RCMs (red: MIROC5RegCM4 and CNRM-RegCM4, purple dashed: NCEP-RegCM4). (b),(d) Mean seasonal cycle of overland precipitation $\left(\mathrm{mm} \mathrm{day}^{-1}\right)$ in the basin for 1980-99. These panels also include data from both adjusted and unadjusted University of Delaware observations in gray shading. The shading's upper edge represents adjusted data and lower edge represents unadjusted data; this gray shading identifies observational uncertainty. Yellow-green highlights in the $x$ axis indicate the months in which the GCM-forced RCM outperforms the parent GCM in terms of mean bias, compared to unadjusted observations.

uncertainty among the models' projections grows during this century, with an across-model standard deviation in mid-twenty-first-century temperature (precipitation) projections of $0.94^{\circ} \mathrm{C}\left(0.12 \mathrm{~mm} \mathrm{day}^{-1}\right)$ and in latetwenty-first-century temperature (precipitation) projections of $1.29^{\circ} \mathrm{C}\left(0.20 \mathrm{~mm} \mathrm{day}^{-1}\right)$.

The choice of MIROC5 and CNRM-CM5 as the two CMIP5 GCMs to dynamically downscale is based on three criteria (see Table S1 in the supplemental material). 1) The GCM should have sufficiently high spatial resolution to avoid a large ratio between the resolution of the parent GCM and RCM (Denis et al. 2002; Antic et al. 2004). Given the spatial resolution of $1.4^{\circ} \times 1.4^{\circ}$ for both MIROC5 and CNRM-CM5, the ratio between the parent GCM and 25-km RCM would be approximately
5.3: 1. 2) The mean seasonal cycle of near-surface air temperature and precipitation in the basin should be satisfactorily simulated based on the root-mean-square differences (rmsd) between observations and the models. The rmsd for temperature is, on average, $1.8^{\circ} \mathrm{C}$ among the models and lower in CNRM-CM5 $\left(1.2^{\circ} \mathrm{C}\right)$ than MIROC5 $\left(2.9^{\circ} \mathrm{C}\right)$ (Figs. 3a,c). Meanwhile, the rmsd for precipitation is, on average, $0.52 \mathrm{~mm} \mathrm{day}^{-1}$ among the models and lower in MIROC5 $\left(0.28 \mathrm{~mm} \mathrm{day}^{-1}\right)$ than CNRM-CM5 (0.37 mm day ${ }^{-1}$ ) (Figs. 3b,d). 3) The final choice of two models should represent the low-end and high-end projected cold season warming trends for the twenty-first century. MIROC5 $\left(+8.3^{\circ} \mathrm{C}\right)$ produces greater warming by the late twenty-first century than does CNRM-CM5 $\left(+5.5^{\circ} \mathrm{C}\right.$ ) (Fig. 2). 
b. Evaluation of dynamically downscaled late-twentieth-century climatology of Great Lakes basin

The mean seasonal cycle of simulated terrestrial (over land) 2-m air temperature and precipitation in the broader Great Lakes region is evaluated against the University of Delaware gridded observations in the two select CMIP5 GCMs (MIROC5 and the CNRM-CM5) and three downscaled RCM models (NCEP-RegCM4, MIROC5-RegCM4, and CNRM-RegCM4) for the late twentieth century (1980-99) (Fig. 3).

Dynamical downscaling leads to an improved climatology of the Great Lakes basin for MIROC5. The rmsd between the observed and simulated seasonal cycle of area-averaged temperature is reduced by $27 \%$ from $2.6^{\circ} \mathrm{C}$ in the parent model, MIROC5, to $1.9^{\circ} \mathrm{C}$ in the downscaled model, MIROC5-RegCM4, with a notable reduction in the GCM's warm bias during JuneAugust (JJA) in the RCM (Fig. 3a). However, MIROC5-RegCM4 exhibits a cold bias in every month outside of JJA. The rmsd between the observed and simulated seasonal cycle of precipitation is reduced by $33 \%$ from $0.43 \mathrm{~mm} \mathrm{day}^{-1}$ in MIROC5 to $0.29 \mathrm{~mm} \mathrm{day}^{-1}$ in MIROC5-RegCM4, with substantial reductions in the GCM's summertime wet bias through dynamical downscaling (Fig. 3b). The number of months that lie within the observed range of unadjusted and adjusted precipitation improves from five in MIROC5 to nine in MIROC5-RegCM4, as further evidence of added value. Nonetheless, both the GCM and RCM produce a year-round wet bias across the United States and Canada. The cold and wet biases in MIROC5-RegCM4 lead to excessive simulated snowfall. The NCEP-forced RegCM4 simulation exhibits an unusual May peak in precipitation and a relative minimum in July-August, both of which are absent in the GCM-forced simulations.

Air temperature biases are substantially lower in CNRM-CM5 and CNRM-RegCM4 than in MIROC5 and MIROC5-RegCM4. Given less room for improvement, there is no apparent added value in dynamically downscaling CNRM in terms of the mean climatology of temperature or precipitation. The rmsd between the observed and simulated seasonal cycle of 2-m air temperature is quite low in both CNRM-CM5 $\left(1.05^{\circ} \mathrm{C}\right)$ and CNRM-RegCM4 $\left(1.16^{\circ} \mathrm{C}\right)$ (Fig. 3c). Likewise, the rmsd for precipitation is $0.41 \mathrm{~mm} \mathrm{day}^{-1}$ in CNRM-CM5 and $0.45 \mathrm{~mm} \mathrm{day}^{-1}$ in CNRM-RegCM4, with downscaling resulting in a diminished wet bias in spring but an amplified wet bias in late summer-early autumn (Fig. 3d). The number of months that lie within the range of the observed unadjusted and adjusted precipitation remains unchanged at seven for both CNRM-CM5 and CNRMRegCM4, indicating no added value. Although temperature is well reproduced by CNRM-RegCM4, its wet bias results in excessive simulated snowfall.

\section{c. Downscaled projections of air temperature and precipitation}

The spatial patterns of projected changes in 2-m air temperature and precipitation during November-March (lake-effect snow season/unstable season; Niziol et al. 1995; Notaro et al. 2013b), by the late twenty-first century, are assessed in MIROC5-RegCM4 and CNRMRegCM4 (Fig. 4). Within MIROC5-RegCM4, the simulated warming ranges from approximately $+3^{\circ} \mathrm{C}$ across the southeastern United States to $+8^{\circ} \mathrm{C}$ across central-eastern Ontario, resulting in a tight meridional gradient of projected warming across the Great Lakes basin (Fig. 4a). Both the overall regional warming and this meridional gradient are weaker in CNRM-RegCM4 (Fig. 4c). While the mean cold season temperatures increase substantially, the impact of climate change on extreme cold air outbreaks, which are critical drivers of lake-effect snow, is much more pronounced. At each grid cell, the 100 coldest nights are identified in each set of downscaled simulations for the late twentieth (1980-99) and late twenty-first (2080-99) centuries. These temperatures are area-averaged across the broader Great Lakes region to determine the mean coldest night temperatures for both time periods. By the late twentyfirst century, episodes of extreme cold are substantially weakened, with projected warming during those specific events of $+10.9^{\circ} \mathrm{C}$ in MIROC5-RegCM4 and $+8.1^{\circ} \mathrm{C}$ in CNRM-RegCM4 (see Fig. S2 in the supplemental material). The projected warming rate for extreme cold events greatly exceeds the projected warming rate for the mean climate, which is indicative of a greater change (large reduction) in extremes.

Both MIROC5-RegCM4 and CNRM-RegCM4 produce regionwide increases in November-April precipitation by the late twenty-first century, including downwind of the lakes (Figs. 4b,d). The increase in total lake-effect precipitation is induced by declining lake ice cover and greater lake evaporation, along with the dynamical mechanisms of greater fetch inferred from enhanced westerlies during November, December, and February in MIROC5-RegCM4 and northerlies in November, December, and March in CNRM-RegCM4 (see Fig. S3 in the supplemental material). Precipitation downwind of the Great Lakes increases by roughly 10\%-30\% during February in MIROC5-RegCM4 and during December and March in CNRM-RegCM4.

The RCM exhibits lower sensitivity to greenhouse gas forcings than its parent GCMs, based on the 


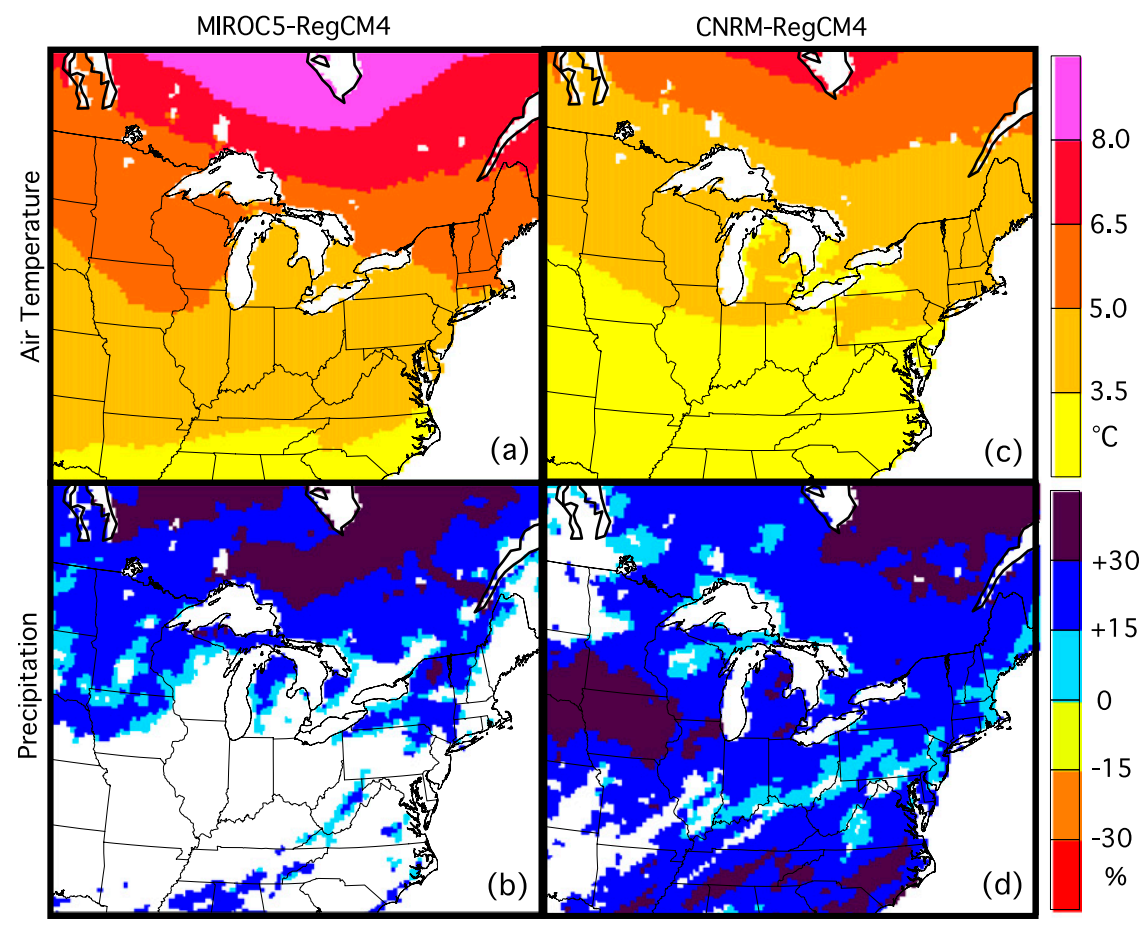

FIG. 4. Projected change in November-March (a),(c) surface air temperature $\left({ }^{\circ} \mathrm{C}\right)$ and (b),(d) precipitation (\%) from (a),(b) MIROC5-RegCM4 and (c),(d) CNRM-RegCM4, computed as the difference between 2080-99 and 1980-99. Only significant differences $(p<0.1)$ are displayed.

late-twenty-first-century projections for DecemberMay across the broader Great Lakes region. Air temperatures are projected to increase by the midtwenty-first and late twenty-first century by $+3.0^{\circ}$ and $+6.1^{\circ} \mathrm{C}$, respectively, in MIROC5-RegCM4 and $+2.2^{\circ}$ and $+4.1^{\circ} \mathrm{C}$, respectively, in CNRM-RegCM4. These $\mathrm{RCM}$-based warming projections are approximately $70 \%$ of those in the original GCMs. While CNRMRegCM4 produces a nearly identical increase in precipitation $\left(+0.31 \mathrm{~mm} \mathrm{day}^{-1}\right.$ by the mid-twenty-first century and $+0.52 \mathrm{~mm} \mathrm{day}^{-1}$ by the late twenty-first century) as CNRM-CM5, the projected increase in precipitation in MIROC5-RegCM4 $\left(+0.15 \mathrm{~mm} \mathrm{day}^{-1}\right.$ by the mid-twenty-first century and $+0.31 \mathrm{~mm} \mathrm{day}^{-1}$ by the late twenty-first century) is only roughly $60 \%$ in magnitude compared to the increase in MIROC5.

\section{d. Downscaled projections of lake temperatures}

While the RCM, coupled to an interactive 1D lake model, can capture the primary characteristics of the seasonal cycle of LSTs for the late twentieth century (1980-99), several key biases are noted in the reanalysisand GCM-forced simulations, namely a winter cold bias and more substantial summer warm bias (Fig. 5). Based on the rmsd between the observed and simulated seasonal cycle of LSTs, MIROC5-RegCM4 slightly outperforms CNRM-RegCM4, with the rmsd ranging from $1.7^{\circ} \mathrm{C}$ for Lake Ontario in both models to $3.6^{\circ} \mathrm{C}$ in MIROC5-RegCM4 and $3.8^{\circ} \mathrm{C}$ in CNRM-RegCM4 for Lake Superior. The deep Lake Superior is generally poorly simulated by a 1D lake model, given the model's lack of a 3D lake circulation. Compared to GLSEA, the RCM simulates a cold LST bias in DJF, ranging from $-1.4^{\circ} \mathrm{C}$ for Lake Superior to $-2.0^{\circ} \mathrm{C}$ for Lake Huron in MIROC5-RegCM and from $-1.0^{\circ} \mathrm{C}$ for Lake Superior to $-1.5^{\circ} \mathrm{C}$ for Lake Huron in CNRM-RegCM4. The greatest LST biases occur during summer, including a $6.3^{\circ} \mathrm{C}$ warm bias on Lake Superior during JJA in MIROC5-RegCM4. The absence of a simulated lake circulation and lack of explicit mixing lead to an anomalously early onset of stratification, an exaggerated spring-early summer rate of warming, and a warm bias in summer (Bennington et al. 2014).

The projected increases in LSTs are smaller on the annual basis, particularly in winter, but greater in late spring-early summer, compared to those of 2-m terrestrial air temperatures within the basin. The magnitude of the projected increase in annual LSTs is typically about $75 \%$ that of the overland air temperatures by the late twenty-first century (Fig. 6). The annual warming of 

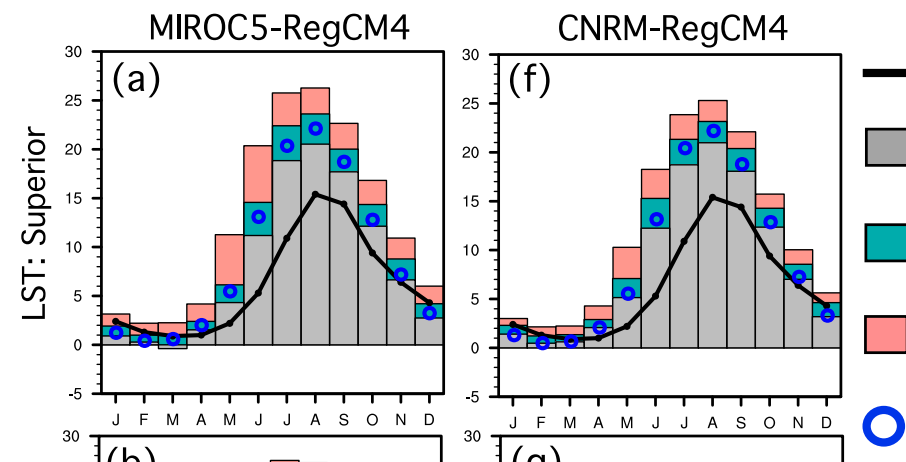

Observed

Simulated Late 20th

Century (GCM-forced)
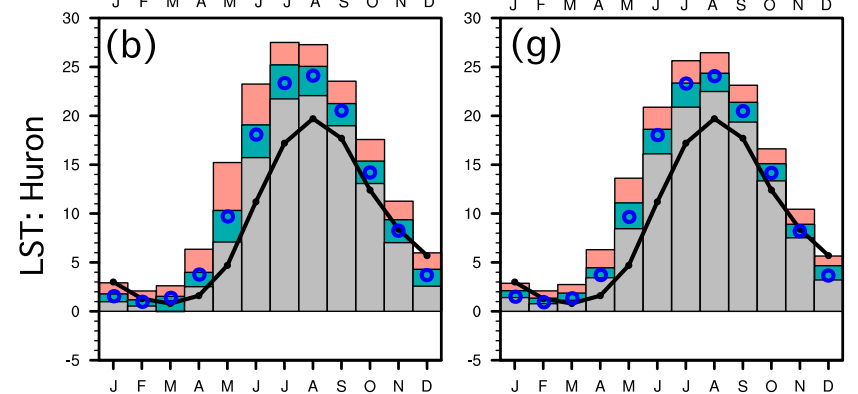

Simulated Mid-21st Century (GCM-forced)

Simulated Late $21 \mathrm{st}$

Century (GCM-forced)

Simulated Late 20th Century (NCEP-forced)
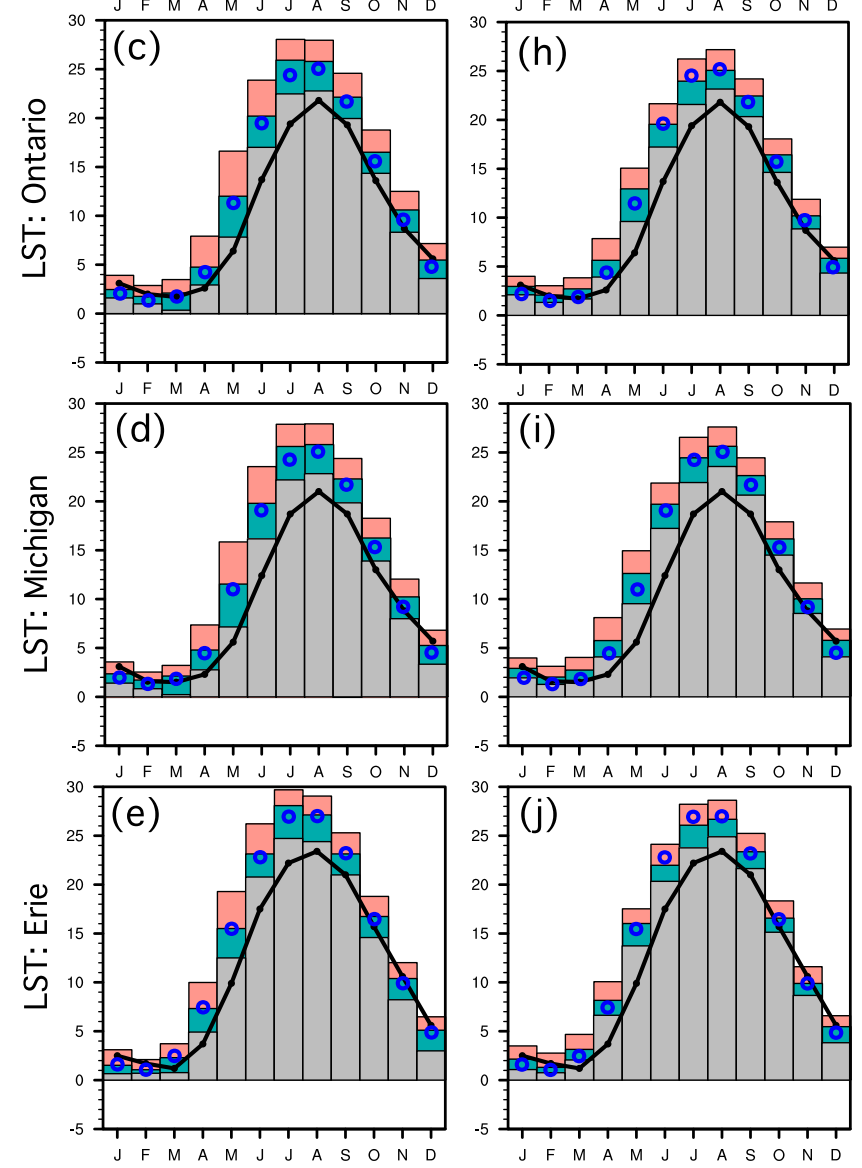

FIG. 5. Mean seasonal cycle of LST $\left({ }^{\circ} \mathrm{C}\right)$ for Lakes (a),(f) Superior, (b),(g) Huron, (c),(h) Ontario, (d),(i) Michigan, and (e),(j) Erie from remote sensing (GLSEA) (black line) and from (left) MIROC5RegCM4, (right) CNRM-RegCM4, and NCEP-RegCM4. Simulated results for the late twentieth century (1980-99) are shown with gray bars for MIROC5-RegCM4 and CNRM-RegCM4 and blue circles for NCEP-RegCM4. Simulated results for the mid- (2040-59) and late twenty-first (2080-99) century are shown with aqua and pink bars, respectively, for downscaled data (MIROC5-RegCM4 and CNRM-RegCM4). Every projected change shown here is significant $(p<0.1)$. 


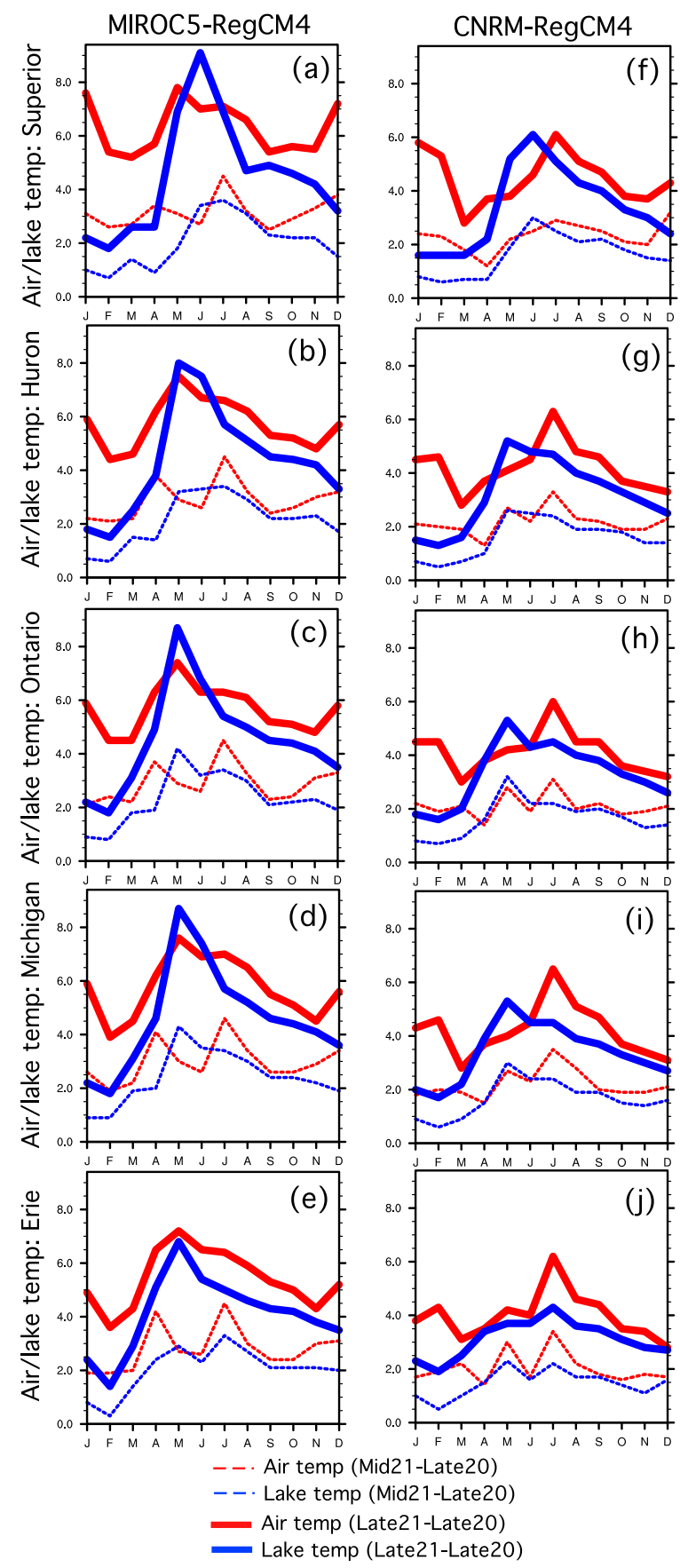

FIG. 6. Seasonal cycle of projected changes in 2-m air temperature over land (red: ${ }^{\circ} \mathrm{C}$ ) and LST (blue: ${ }^{\circ} \mathrm{C}$ ) for Lakes (a),(f) Superior, (b),(g) Huron, (c),(h) Ontario, (d),(i) Michigan, and (e),(j) Erie, based on (left) MIROC5-RegCM4 and (right) CNRMRegCM4, computed as the difference between either 2040-59 (thin dashed) or 2080-99 (thick solid) and 1980-99. RCM-based projections of overland air temperatures are computed using these Great Lake regions: Superior $\left(45.3^{\circ}-50.1^{\circ} \mathrm{N}, 82.3^{\circ}-93.1^{\circ} \mathrm{W}\right)$, Huron $\left(41.8^{\circ}-47.4^{\circ} \mathrm{N}, \quad 78.1^{\circ}-86.2^{\circ} \mathrm{W}\right)$, Ontario $\left(41.8^{\circ}-45.8^{\circ} \mathrm{N}, \quad 74.6^{\circ}-\right.$ $\left.80.8^{\circ} \mathrm{W}\right)$, Michigan $\left(40.7^{\circ}-47.2^{\circ} \mathrm{N}, 83.7^{\circ}-89.8^{\circ} \mathrm{W}\right)$, and Erie $\left(40.0^{\circ}-\right.$ $\left.44.5^{\circ} \mathrm{N}, 77.4^{\circ}-84.7^{\circ} \mathrm{W}\right)$. Every LST and air temperature change shown here is significant $(p<0.1)$. individual lakes by the late twenty-first century does not exhibit much heterogeneity, with projected increases in annual LST ranging from $4.1^{\circ} \mathrm{C}\left(3.1^{\circ} \mathrm{C}\right)$ for Lake Erie to $4.6^{\circ} \mathrm{C}\left(3.4^{\circ} \mathrm{C}\right)$ for Lake Michigan in MIROC5-RegCM4 (CNRM-RegCM4). However, across-lake differences in LST sensitivities become much more pronounced during June-July, such as in MIROC5-RegCM4, with Lake Erie warming by $+5.4^{\circ} \mathrm{C}$ compared to $+9.1^{\circ} \mathrm{C}$ of warming on Lake Superior. In general, the lake surface is projected to warm more than the terrestrial air during May-June, particularly for the deepest lake, Superior, but not true for shallow Lake Erie. MIROC5-RegCM4 simulates an increase in Superior's LST of $9.1^{\circ} \mathrm{C}$ in June, compared to $+7.1^{\circ} \mathrm{C}$ in 2-m air temperature, by the late twenty-first century. This is consistent with the observed trend of rapid LST warming of Lake Superior during July-September (JAS) compared to the rate of warming of the near-surface air temperature over surrounding land (Austin and Colman 2007); however, because of the 1D lake model's bias toward an early stratification, the timing of most rapid warming occurs in late spring-early summer rather than in mid-to-late summer as observed. During November-March, air temperature is projected to increase more than water temperature, leading to diminished sensible heat fluxes, greater atmospheric stability, and a shallower atmospheric boundary layer.

A comparison of the seasonal cycle in vertical lake temperature profiles between GLERL measurements for central Lake Michigan and output from the reanalysis- and GCM-driven RegCM4 simulations reveals that the simulated timing of stratification is typically one month too early (Figs. 7a-d), which is also true for Lakes Superior and Huron according to buoy observations, allowing the lake to warm up too much by midto-late summer. Projected lake warming and diminished ice cover by the late twenty-first century support an even earlier stratification by roughly one month, compared to the late twentieth century, in both MIROC5-RegCM4 and CNRM-RegCM4 (Figs. 7e,f). Based on the vertical gradient in water temperature across the upper $15 \mathrm{~m}$, stability of the lake column is projected to increase substantially during May-June.

\section{e. Downscaled projections of lake ice cover and turbulent fluxes}

RegCM4 produces a fair representation of both the spatial distribution and seasonal evolution of Great Lakes' ice cover, although the lack of horizontal mixing and ice motion in the 1D lake causes an excessive and overly persistent ice cover, particularly for Lake Superior, with ice developing too early (Notaro et al. 2013b) (Figs. 8 and 9). CNRM-RegCM4 outperforms MIROC5RegCM4 in terms of its simulated seasonal cycle of ice 

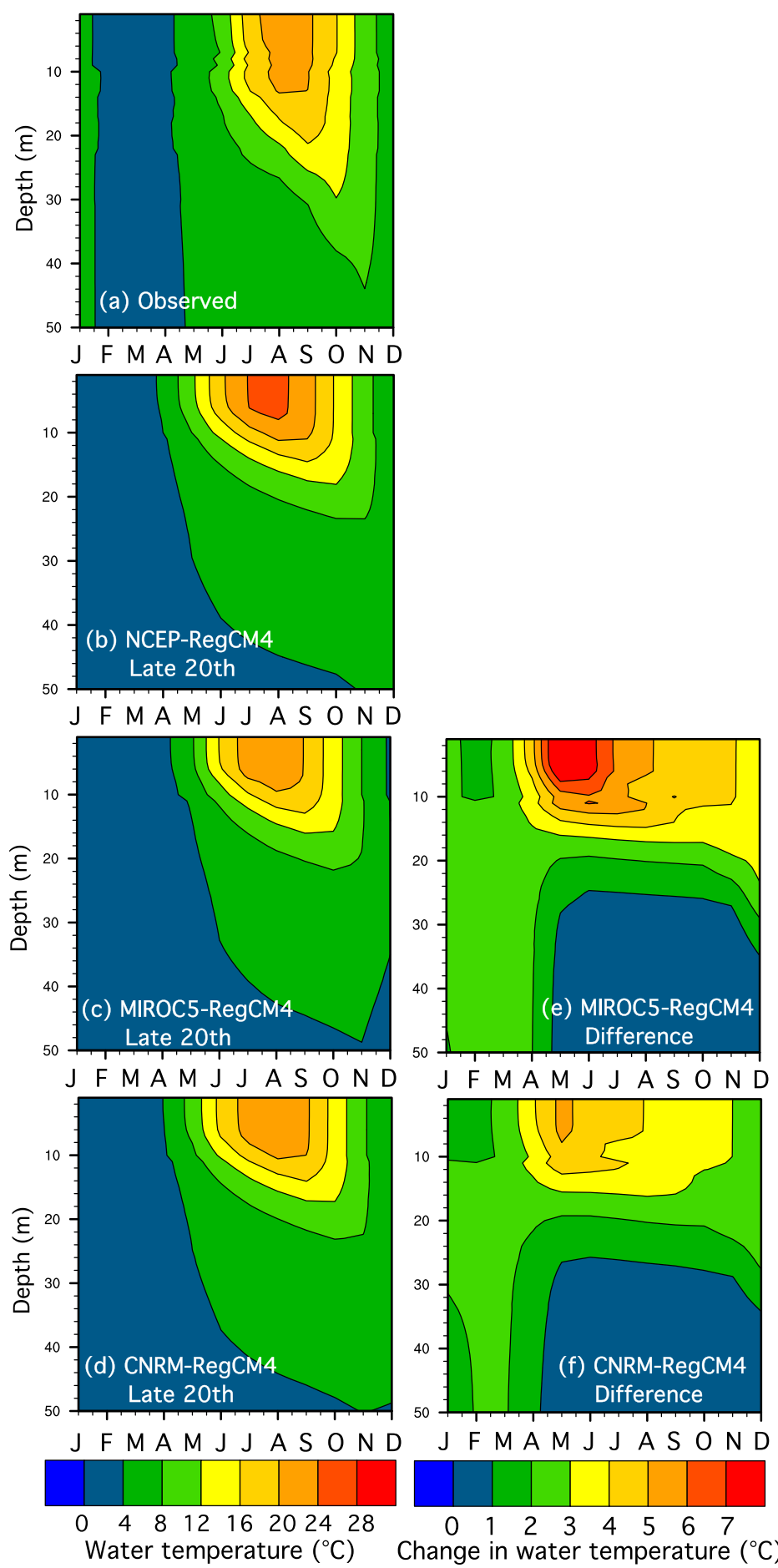

FIG. 7. Seasonal cycle of the mean vertical temperature profile $\left({ }^{\circ} \mathrm{C}\right)$ for the top $50 \mathrm{~m}$ of Lake Michigan, from (a) observations (NOAA/GLERL, 1995-2010), (b) NCEP-RegCM4, (c),(e) MIROC5-RegCM4, and (d),(f) CNRMRegCM4. Results are shown for the late twentieth century (1980-99) in (b)-(d) and the projected difference between the late twenty-first and late twentieth centuries (2080-99 minus 1980-99) in (e) and (f). Observed results are shown for a midlake location, while model results are the lake average. The bottomleft color bar pertains to (a)-(d) and the bottom-right one to (e) and (f). The entire difference fields in (e) and (f) are significant $(p<0.1)$. 

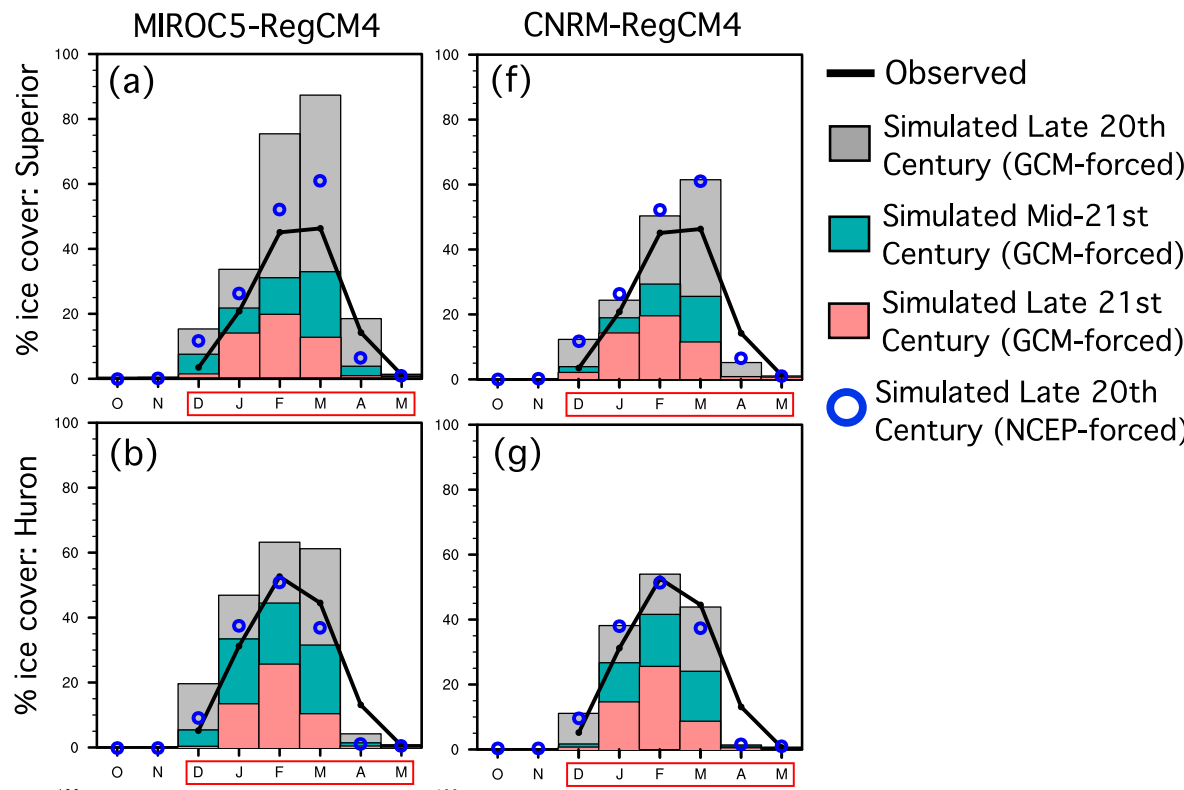

Simulated Late 20th
Century (GCM-forced)

Simulated Mid-21st

Century (GCM-forced)

Simulated Late 21 st

Century (GCM-forced)

Simulated Late 20th
Century (NCEP-forced)
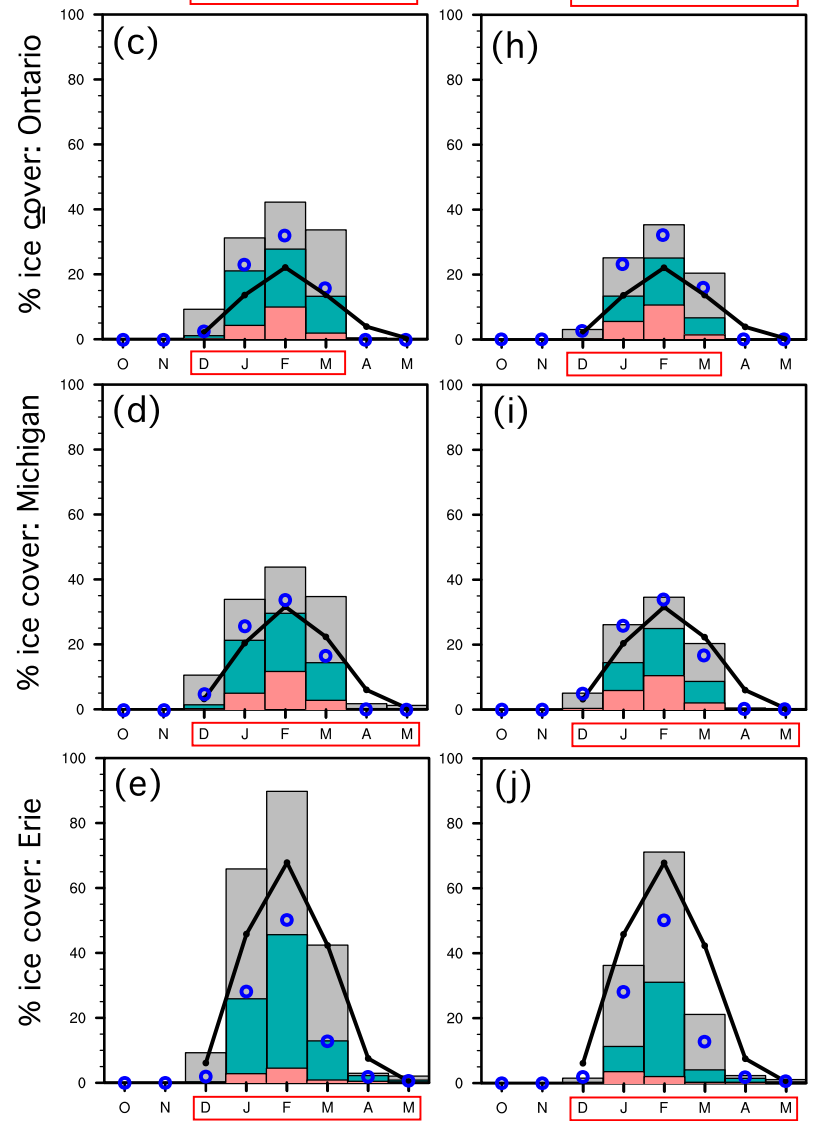

FIG. 8. Mean seasonal cycle (October-May) of percent lake ice cover across Lakes (a),(f) Superior, (b),(g) Huron, (c),(h) Ontario, (d),(i) Michigan, and (e),(j) Erie from NOAA's Great Lakes Ice Atlas (black line) and from (left) MIROC5-RegCM4, (right) CNRM-RegCM4, and NCEP-RegCM4. Simulated results for the late twentieth century (1980-99) are shown with gray bars for MIROC5-RegCM4 and CNRM-RegCM4 and blue circles for NCEP-RegCM4. Simulated results for the late (mid) twenty-first century (2080-99) from MIROC5-RegCM4 and CNRMRegCM4 are shown with pink (aqua) bars. Red rectangles in the $x$ axis indicate time periods with significant $(p<0.1)$ reductions in mean ice cover by both mid- and late twenty-first century. 


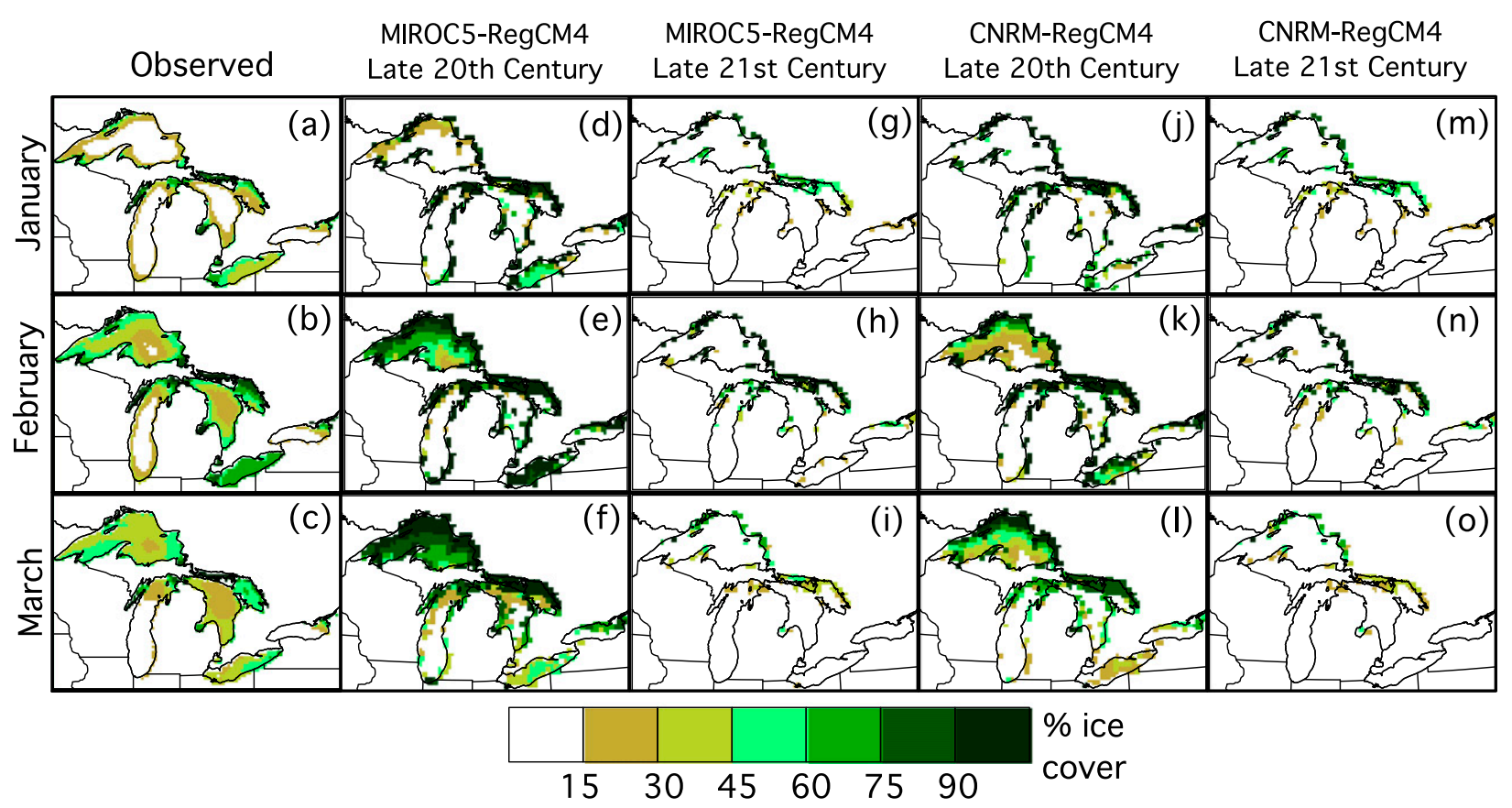

FIG. 9. Mean percent ice cover for January-March across the Great Lakes, from (a)-(c) observations, (d)-(i) MIROC5-RegCM4, and (j)-(o) CNRM-RegCM4, for the late twentieth century (1980-99) in (a)-(f),(j)-(l) and for the late twenty-first century (2080-99) in (g)(i),(m)-(o). Observations are retrieved from NOAA's Great Lakes Ice Atlas (using Canadian Ice Service data).

cover for the late twentieth century, given the excessive ice cover (Figs. 8a-e) in the latter model configuration due to its cold bias (Fig. 3a). Compared to the Great Lakes Ice Atlas, MIROC5-RegCM4 produces excessive ice cover over every lake during December-April, particularly Lakes Superior $(46.0 \%$ in model versus $26.0 \%$ in observations) and Michigan (24.9\% in model versus $16.7 \%$ in observations) and most notably in February-March. CNRM-RegCM4 performs better, with a modest positive bias in ice cover on Lake Ontario (16.8\% in model versus $11.1 \%$ in observations) and negative bias on Lake Erie ( $26.4 \%$ in model versus $33.9 \%$ in observations).

In response to projected warming, Great Lakes' ice cover rapidly declines during the twenty-first century, with the largest reductions in February-March (Fig. 8). The most pronounced reductions by the late twenty-first century are simulated for Lake Erie during February on the order of $-85 \%$ in MIROC5-RegCM 4 and $-69 \%$ in CNRM-RegCM4. During the late twentieth century, in both the model and observations, ice develops along the shallow shores in December and becomes most extensive in February-March, with the greatest ice cover over Lakes Superior (coldest environment) and Erie (shallowest lake) (Figs. 9a-f,j-1). By the late twenty-first century, ice becomes primarily restricted to the northern shores, leaving most of the lakes as open water even in midwinter, with ice only typically developing during January-March (Figs. 9g-i,m-o).
In response to declining lake ice cover and enhanced wind speed, lake evaporation increases during the twenty-first century during October-May, which supports greater total lake-effect precipitation (see Fig. S4 in the supplemental material). Latent heat fluxes during October-May increase by $5-6 \mathrm{~W} \mathrm{~m}^{-2}$ in CNRMRegCM4 and $8-10 \mathrm{~W} \mathrm{~m}^{-2}$ in MIROC5-RegCM4, depending on the lake (Fig. 10). Given that the lower tropospheric air temperature increases more than the LST by the late twenty-first century during the cold season, sensible heat fluxes greatly diminish, particularly in January-February and over Lake Superior. Projected reductions in sensible heat flux during October-May range from $-14 \mathrm{~W} \mathrm{~m}^{-2}$ for Lake Erie to $-27 \mathrm{~W} \mathrm{~m}^{-2}$ for Lake Superior in CNRM-RegCM4 and from $-22 \mathrm{~W} \mathrm{~m}^{-2}$ for Lake Michigan to $-37 \mathrm{~W} \mathrm{~m}^{-2}$ for Lake Superior in MIROC5-RegCM4 (Fig. 10).

\section{f. Downscaled snowfall projections}

As demonstrated by Notaro et al. (2013b, 2014), because of their coarse spatial resolution and poor representation of the Great Lakes, the CMIP3 and CMIP5 models struggle to capture mean lake-effect snowfall patterns, while dynamical downscaling with RegCM4 coupled to an interactive lake model leads to a reasonable snowfall distribution across the basin (Figs. 11a-d). Unfortunately, temperature and precipitation biases in the RCM (e.g., MIROC5-RegCM4's cold bias) and 

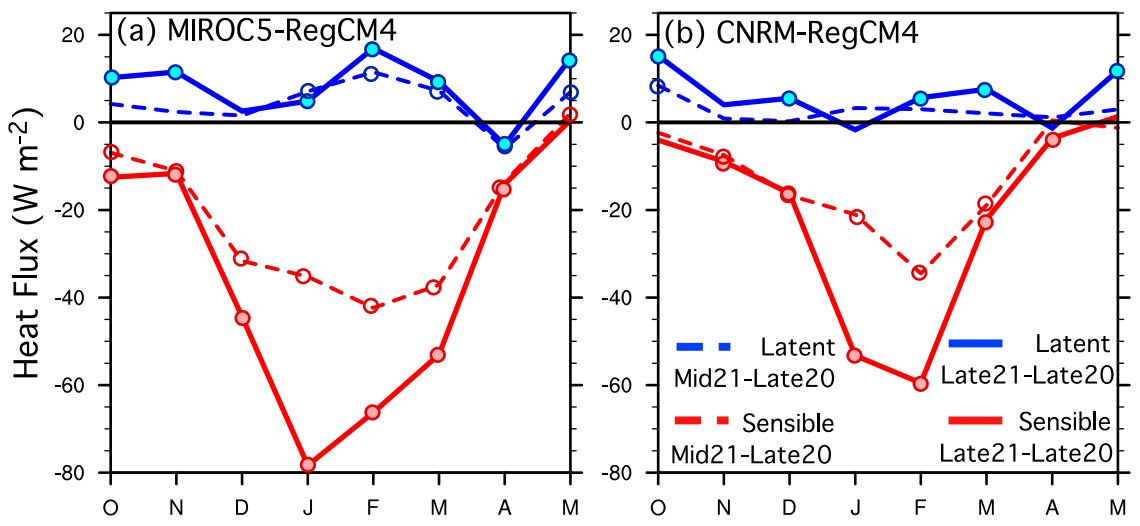

FIG. 10. Seasonal cycle of projected changes in mean overlake sensible (red) and latent (blue) heat fluxes $\left(\mathrm{W} \mathrm{m}^{-2}\right)$ for the Great Lakes from (a) MIROC5-RegCM4 and (b) CNRMRegCM4, computed as the difference between either 2040-59 (dashed) or 2080-99 (solid) and 1980-99. Open and filled circles identify significant differences $(p<0.1)$ for the mid- and late twenty-first century, respectively.

undercatchment issues in the observations support an apparent excessive snow bias in RegCM4. Based on a comparison between station observations and simulated snowfall downwind of the lakes, MIROC5-RegCM4 (CNRM-RegCM4) exhibits a mean annual snowfall bias that ranges from $-11 \%(-20 \%)$ downwind of Lake Superior to $+62 \%(+48 \%)$ downwind of Lake Ontario (Fig. 12). The RCM successfully captures the peaks in daily snowfall event frequency $(\geq 1 \mathrm{~cm})$ downwind of each lake in excess of 50 days $\mathrm{yr}^{-1}$, although the simulated snowfall frequency maxima extend too far from the lakeshores (Fig. 13) (Notaro et al. 2013b). The model simulates too frequent days with snowfall in the basin. For example, the observed and simulated frequencies are 30.4 and 39.5 days $\mathrm{yr}^{-1}$, respectively, in MIROC5-RegCM4 for the late twentieth century.

Annual snowfall is projected to decline across the Great Lakes basin, Midwest, and northeastern United States by both the mid- and late twenty-first century, with the largest declines by the late twenty-first century across the U.S. Northeast, exceeding $130 \mathrm{~cm}$ in MIROC5RegCM4 and $90 \mathrm{~cm}$ in CNRM-RegCM4 (Figs. 11e,f). The former model produces greater warming, thereby converting more precipitation into the form of rain. MIROC-RegCM4 simulates reductions in mean annual snowfall by the late twenty-first century that range from $-34 \%$ downwind of Lake Superior to $-46 \%$ downwind of Lake Michigan, with the largest reductions in November for all lakes (Figs. 12a-e). Projected snowfall reductions by the late twenty-first century are slightly lower in CNRM-RegCM4, ranging from $-30 \%$ downwind of Lake Superior to $-41 \%$ downwind of Lake Michigan, with peak reductions during NovemberJanuary for all lakes (Figs. $12 \mathrm{f}-\mathrm{j}$ ). Projections by the mid-twenty-first century include modest, statistically insignificant increases in mid-to-late winter snowfall downwind of Lake Superior in February-March and of Lakes Ontario and Erie in January by MIROC5RegCM4, in addition to large reductions in snowfall during late autumn-early winter. Downwind of the lakes, the frequency of snowfall days is projected to decline by the late twenty-first century by roughly 15-25 days $\mathrm{yr}^{-1}$, with additional large reductions in frequency over southern Ontario and Quebec (Fig. 13).

The frequency of heavy lake-effect snow days across the Great Lakes basin is projected to decline by the late twenty-first century by $-46 \%$ in MIROC5-RegCM 4 and $-35 \%$ in CNRM-RegCM4 (Fig. 14), although lakeeffect snowstorms will continue to occur throughout the century. Projections by the mid-twenty-first century are less certain around Lake Superior, with MIROC5RegCM4 simulating an increased frequency of heavy lake-effect snowstorms, where mean snowfall also modestly increases during February-March, and CNRMRegCM4 simulating mostly weak reductions in frequency. Air temperatures are climatologically lowest around Lake Superior compared to the other lakes, allowing lake-effect precipitation events to continue to fall as snow in midwinter despite large projected warming. Declining ice cover, enhanced evaporation, and enhanced fetch support an increase in total lake-effect precipitation, but primarily with a large increase in rainfall and decrease in snowfall. In MIROC5-RegCM4, a projected reduction in sea level pressure across southern Canada by the late twenty-first century contributes dynamical support for increased lake-effect precipitation by enhancing northwesterly winds across the lakes in November, December, and February. It is 
(a) Observed

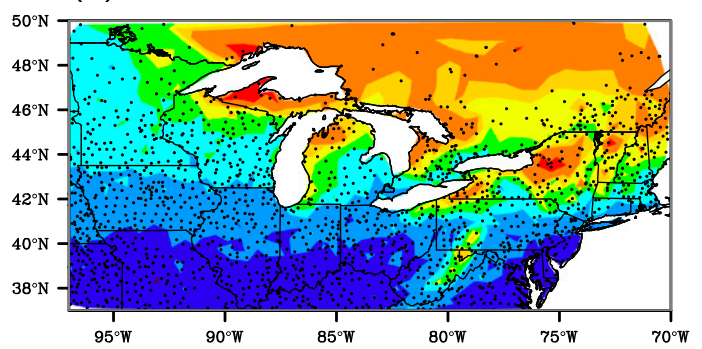

(c) MIROC5-RegCM4 Late 20th Century (b) NCEP-RegCM4 Late 20th Century

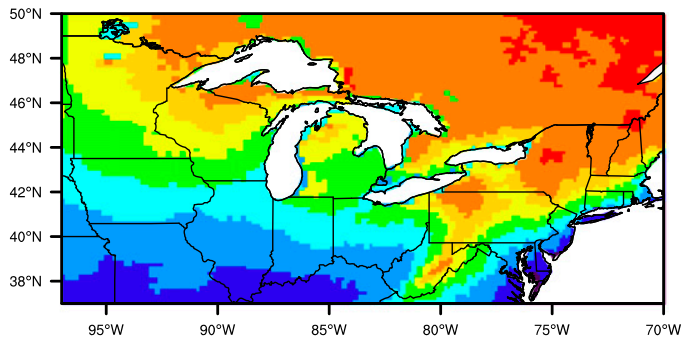

(d) CNRM-RegCM4 Late 20th Century

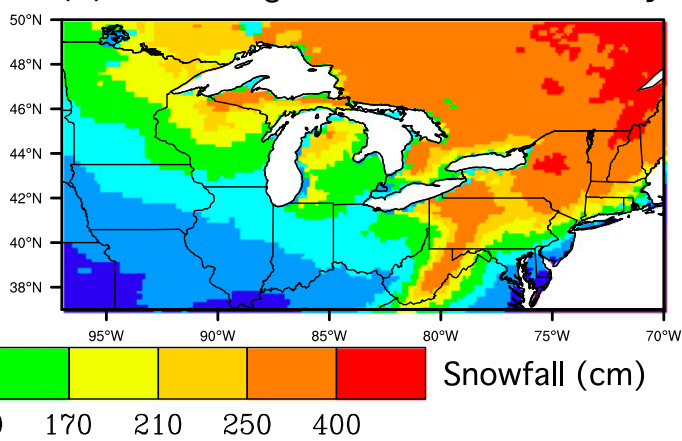

(f) CNRM-RegCM4 Diff (Late21-Late20)

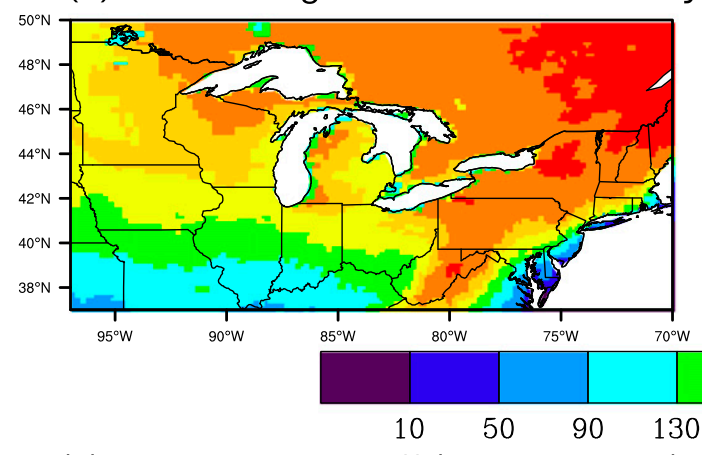

(e) MIROC5-RegCM4 Diff (Late21-Late20)
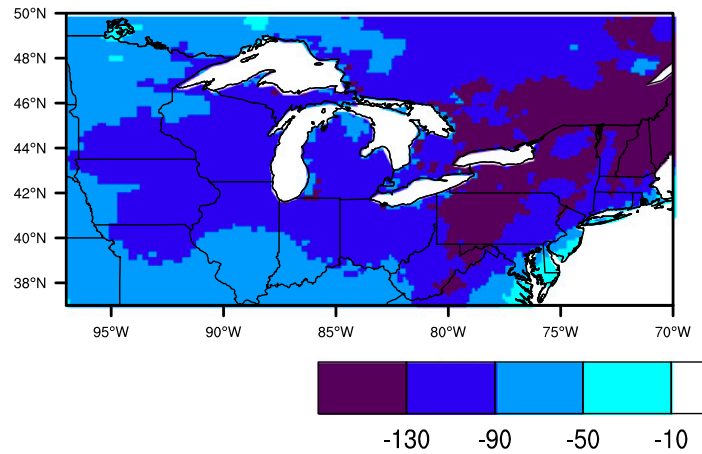

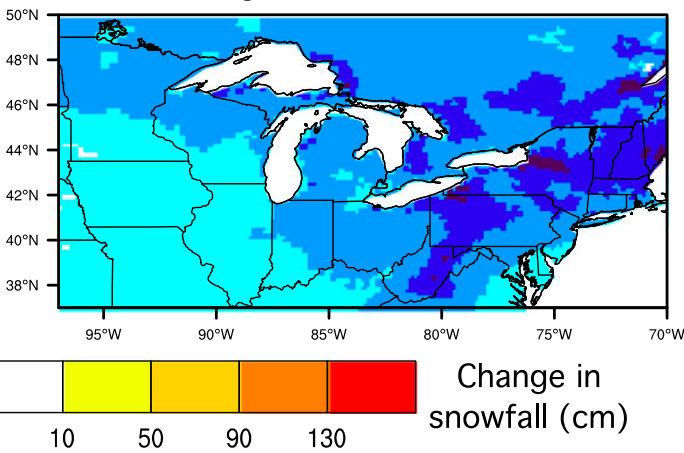

FIG. 11. Mean annual snowfall (cm) from (a) observations (NCDC's high-resolution U.S. Cooperative Observer Dataset and Environment Canada data), (b) NCEP-RegCM4, (c) MIROC5-RegCM4, and (d) CNRM-RegCM4 for the late twentieth century (1980-99). Projected differences in mean annual snowfall $(\mathrm{cm})$ between the late twentyfirst and late twentieth centuries (2080-99 minus 1980-99) are shown for (e) MIROC5-RegCM4 and (f) CNRMRegCM4. In (e) and (f), only significant differences $(p<0.1)$ are displayed.

noted that projected changes in heavy lake-effect snowstorm frequency, based on a less strict set of criterion than those outlined in section $2 \mathrm{c}$, are highly consistent with those presented here, verifying the robustness of these findings.

The seasonality of heavy lake-effect snowstorms is projected to change notably by the late twenty-first century, with a compression of the lake-effect snow season (Fig. 15). Heavy lake-effect snowfall days become primarily confined to mid-to-late winter, namely January-March, and much less frequent in the transition months of November and April. Snowstorms downwind of Lake Erie are particularly responsive in MIROC5RegCM4, with a shift in the peak month of heavy lake-effect snowstorm activity from December in the late twentieth century to January in the mid-twenty-first century to February in the late twenty-first century (Fig. 15e).

The snow season in the Great Lakes basin is likely to become substantially compressed during the twenty-first century in response to warming (Fig. 16). By the midtwenty-first century, MIROC5-RegCM4 and CNRMRegCM4 simulate modest increases in annual precipitation on the order of $+4 \%$ and $+7 \%$, respectively, with increases in annual rainfall ( $+13 \%$ in both models) coming at the expense of decreases in annual snowfall ( $-16 \%$ in MIROC5-RegCM4 and $-12 \%$ in CNRMRegCM4). Likewise, annual precipitation is projected 

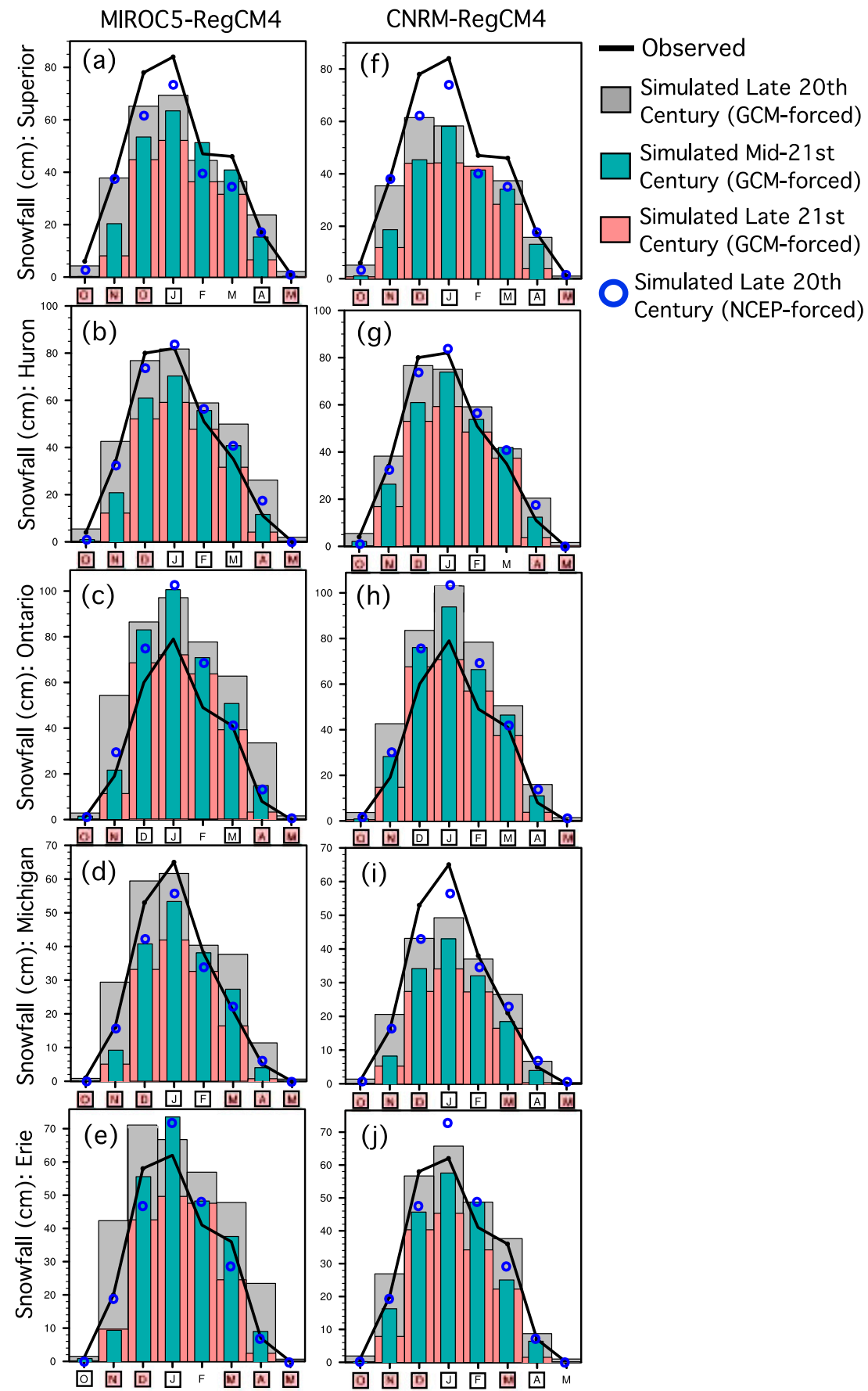

FIG. 12. Mean seasonal cycle (October-May) of monthly mean snowfall (cm) downstream of Lakes (a),(f) Superior, (b), (g) Huron, (c),(h) Ontario, (d),(i) Michigan, and (e),(j) Erie, from observations (black line) and from (left) MIROC5-RegCM4, (right) CNRMRegCM4, and NCEP-RegCM4. Simulated results for the late twentieth century (1980-99) are shown with gray bars for MIROC5-RegCM4 and CNRM-RegCM4 and blue circles for NCEP-RegCM4. For both MIROC5-RegCM4 and CNRM-RegCM4, simulated results for the mid-twenty-first (2040-59) and late twenty-first (2080-99) century are shown with aqua and pink bars, respectively. The downstream regions (averaged over land, within $100 \mathrm{~km}$ of lakeshore) are as in Fig. 1 for Lakes Erie, Ontario, Huron, Superior, and Michigan with the number of stations per region of $97,47,45,37$, and 62 , respectively. In the $x$ axis, unfilled squares around months indicate that the projected change is only significant $(p<0.1)$ by the late twenty-first century and red filled squares indicate the months in which projected changes are significant both by mid- and late twenty-first century. 
(a) Observed

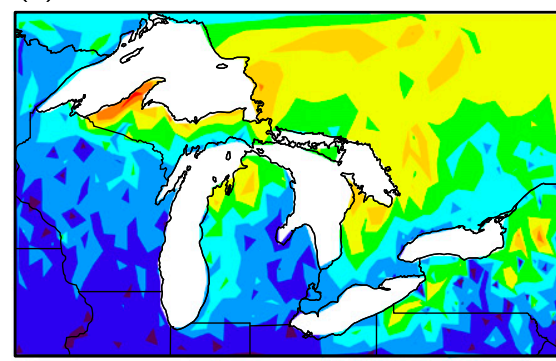

(c) MIROC5-RegCM4 Late 20th Century (b) NCEP-RegCM4 Late 20th Century

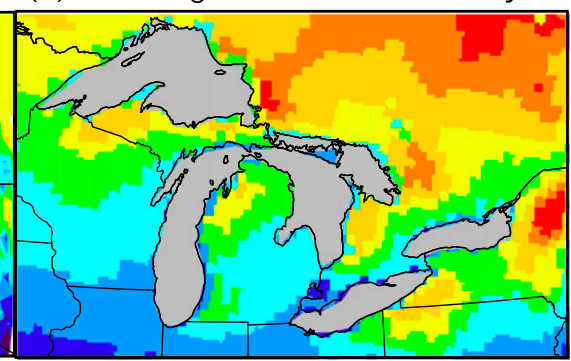

(d) CNRM-RegCM4 Late 20th Century

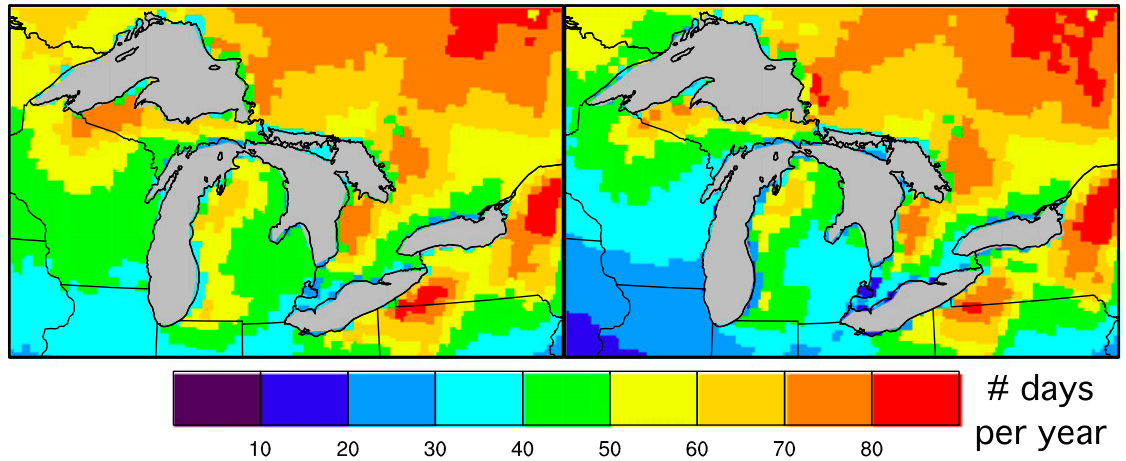

(e) MIROC5-RegCM4 Diff (Late21-Late20)

(f) CNRM-RegCM4 Diff (Late21-Late20)

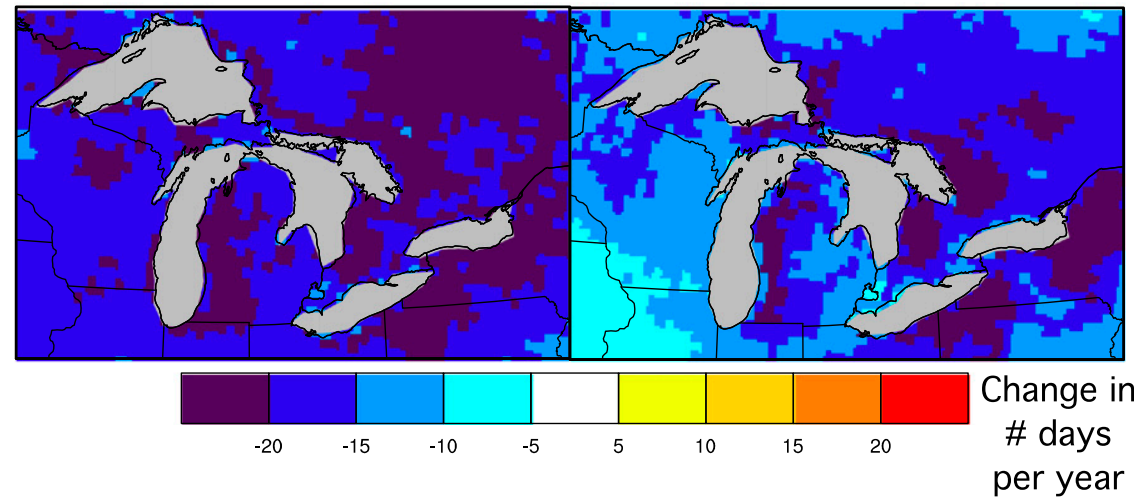

FIG. 13. Mean frequency of daily snowfall $\left(\right.$ days $\left.\mathrm{yr}^{-1}\right)$ of at least $1 \mathrm{~cm}$ in (a) observations, (b) NCEP-RegCM4, (c) MIROC5-RegCM4, and (d) CNRM-RegCM4 for the late twentieth century (1980-99). Also shown is the projected change in this frequency from (e) MIROC5RegCM4 and (f) CNRM-RegCM4, computed as the difference between 2080-99 and 1980-99. The entire difference fields in (e) and (f) are significant $(p<0.1)$.

by the late twenty-first century to increase by $+10 \%$ in MIROC5-RegCM 4 and $+15 \%$ in CNRM-RegCM 4 , with dramatic increases in annual rainfall $(+26 \%$ in MIROC5-RegCM4 and $+28 \%$ in CNRM-RegCM4) and decreases in annual snowfall $(-29 \%$ in MIROC5RegCM4 and $-25 \%$ in CNRM-RegCM4). By the late twenty-first century, the largest percentage declines in the probability of falling precipitation occurring as snow are simulated in November. For example, within the basin, this probability in November drops from $54 \%$ in the late twentieth century to $14 \%$ in the late twenty-first century for MIROC5-RegCM4.

\section{Discussion and conclusions}

The future impacts of anthropogenic climate change on lake ice cover and lake-effect snowfall in the Laurentian Great Lakes basin are investigated. The observational record has shown a distinct positive trend in lake-effect snowfall, because of declining lake ice cover and enhanced evaporation (Burnett et al. 2003). The Great Lakes' ice cover is likely to continue to decline, because of future warming of the atmosphere, which would suggest a persistent positive trend in lake-effect snowfall. However, as intense cold air outbreaks from 

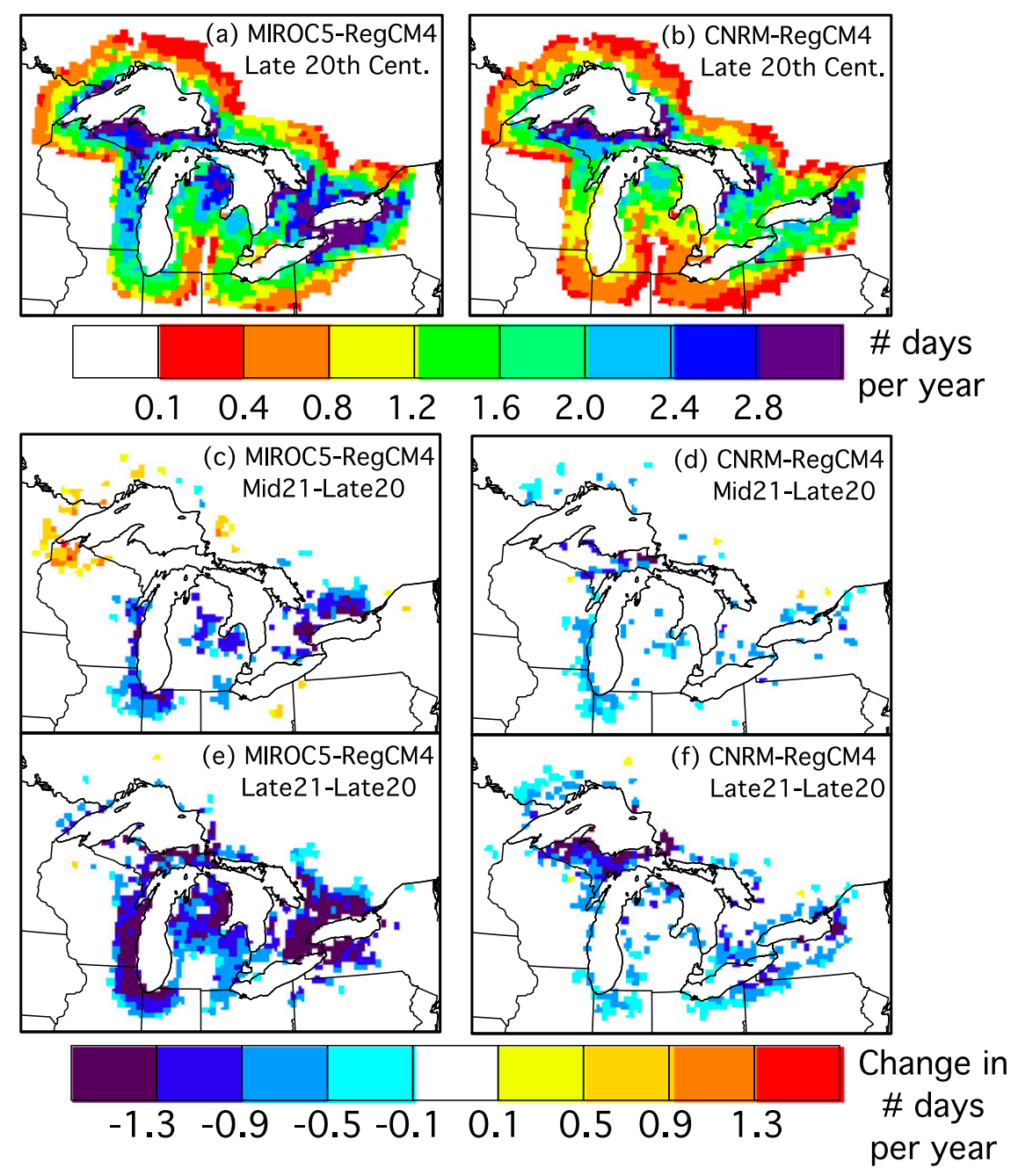

FIG. 14. Mean number of simulated heavy lake-effect snowfall days per year from (a) MIROC5-RegCM4 and (b) CNRM-RegCM4, for the late twentieth century (1980-99). Projected changes in this frequency are shown for (c),(e) MIROC5-RegCM4 and (d),(f) CNRM-RegCM4, computed as the difference between either 2040-59 in (c) and (d) or 2080-99 in (e) and (f) and 1980-99. Only significant differences $(p<0.1)$ in (c)-(f) are displayed.

Canada become less frequent during the twenty-first century (Vavrus et al. 2006), fewer lake-effect snowstorms may be triggered, thereby reversing this positive trend at some point. These opposing hypotheses are explored in the present study. Only two prior published studies have attempted to develop future projections of lake-effect snowfall for the Great Lakes basin. First, Kunkel et al. (2002) inferred changes in lake-effect snowstorm frequency based on changes in the frequency of favorable large-scale atmospheric conditions within GCMs. Second, Gula and Peltier (2012) explicitly simulated lake-effect snowstorms in an RCM, which lacked two-way lake-atmosphere coupling. The current study is therefore the first application of an interactively coupled RCM and lake model to develop explicit projections of lake-effect snow for the Great Lakes basin.

Winter-spring projections for the twenty-first century of higher air temperatures and greater precipitation across the broader Great Lakes region are robust across the pool of 33 CMIP5 GCMs analyzed in this study. In recognition of the coarse resolution and poor representation of the Great Lakes in the CMIP5 models, simulations from two select GCMs (CNRM-CM5 and MIROC5) with contrasting warming projections are dynamically downscaled for the late twentieth, midtwenty-first, and late twenty-first centuries using the 25-km RegCM4, interactively coupled to a 1D lake model. Evaluation of these CNRM-RegCM4 and 

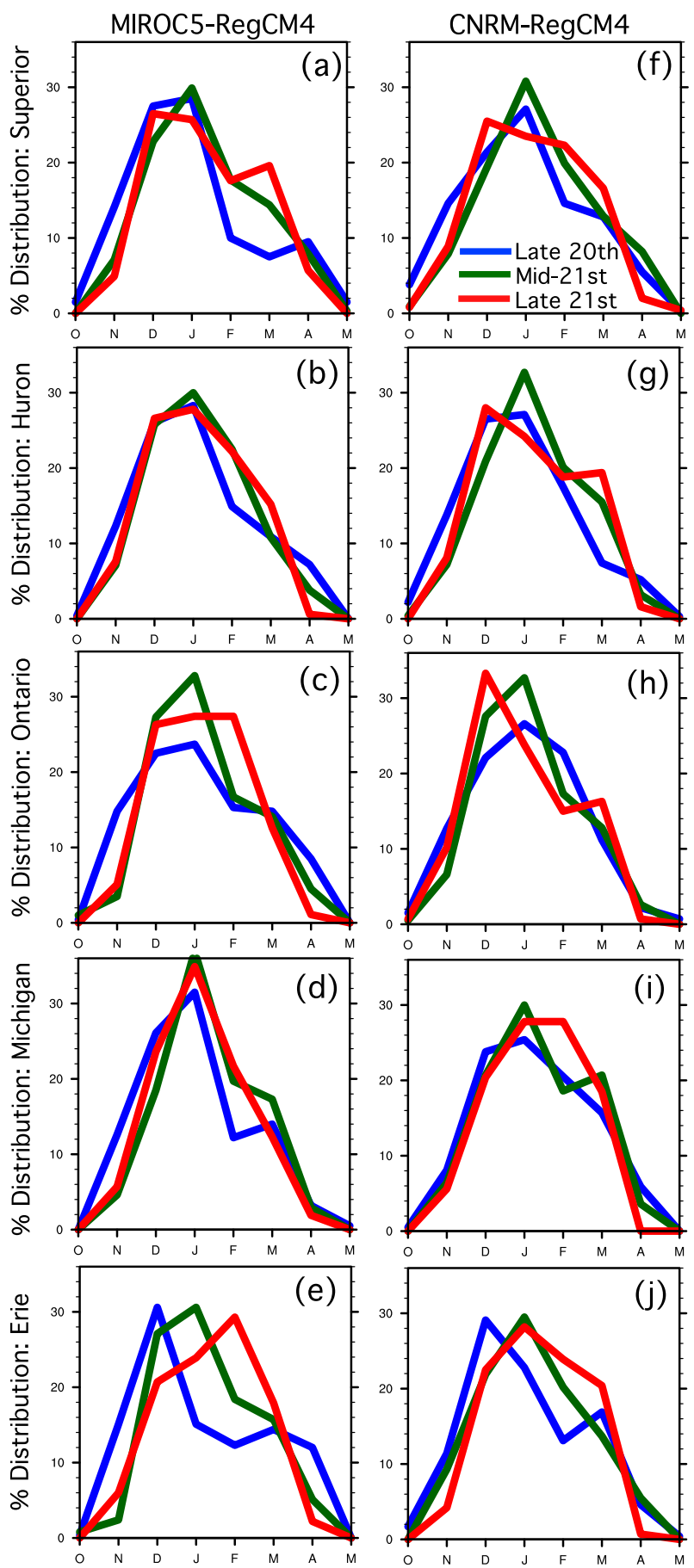

FIG. 15. Seasonal distribution of the percent frequency of simulated heavy lake-effect snowstorms occurring during OctoberMay, for the late twentieth (blue: 1980-99), mid-twenty-first (green: 2040-59), and late twenty-first (red: 2080-99) centuries, from (left) MIROC5-RegCM4 and (right) CNRM-RegCM4. Results are shown for areas downwind of Lakes (a),(f) Superior, (b),(g) Huron, (c),(h) Ontario, (d),(i) Michigan, and (e),(j) Erie.
MIROC5-RegCM4 simulations, along with an additional RegCM4 simulation forced by reanalysis data, confirms the following regional biases previously identified by Notaro et al. (2013b) and Bennington et al. (2014). The lack of horizontal heat advection in the lakes and ice movement leads to a prolonged simulated ice season with excessive maximum ice cover. While freshwater heat capacity and shortwave attenuation are the primary controls of lake temperature, lake circulation can significantly redistribute heat across large lakes in reality but not in the model (Bennington et al. 2014). The absence of a simulated lake circulation leads to excessive winter ice cover, as nothing can prevent ice formation once the surface water cools, even though winds and open lake surface currents are observed to be strongest during winter prior to the development of extensive ice cover (Bennington et al. 2010, 2014). The lakes stratify too early in the model, contributing to a substantial summertime warm bias of the lake surfaces. Because of cold and/or wet biases, both CNRM-RegCM4 and MIROC5RegCM4 produce excessive snowfall.

By the late twenty-first century, RegCM4 simulates declining ice cover (mean ice cover becomes confined to shallow northern lakeshores), earlier lake stratification, and substantial warming of the lower atmosphere and lakes, with increases in LSTs that exceed those of terrestrial near-surface air temperatures during late spring-early summer. The projected increase in lake column stability for late spring-early summer, especially for Lake Erie, would support an increase in the risk for anoxia within deeper water and potential "dead zones" (Blumberg and Di Toro 1990; Hawley et al. 2006; Diaz and Rosenberg 2008; Committee on Environment and Natural Resources 2010). Reduced ice cover and enhanced fetch favor greater evaporation, in support of an increase in total lake-effect precipitation downwind of the lakes, while sensible heat fluxes are projected to dramatically decline as the lower atmosphere warms more than the lake surface during the cold season. Annual snowfall is simulated to decline across the Great Lakes basin by both the mid- and late twenty-first century, with a compression of the snow season's duration. Downwind of the lakes, snowfall is projected to rapidly diminish during November-December, but potentially slightly increase during mid-to-late winter by the midtwenty-first century.

An objective definition for identifying heavy lakeeffect snow days in RCM output (Notaro et al. 2013b) is applied to the RegCM4 downscaled simulations. Heavy lake-effect snowstorms may become more frequent around Lake Superior by the mid-twenty-first century but later decline in occurrence, while projections for the other lakes' basins for both the mid- and late twenty-first 


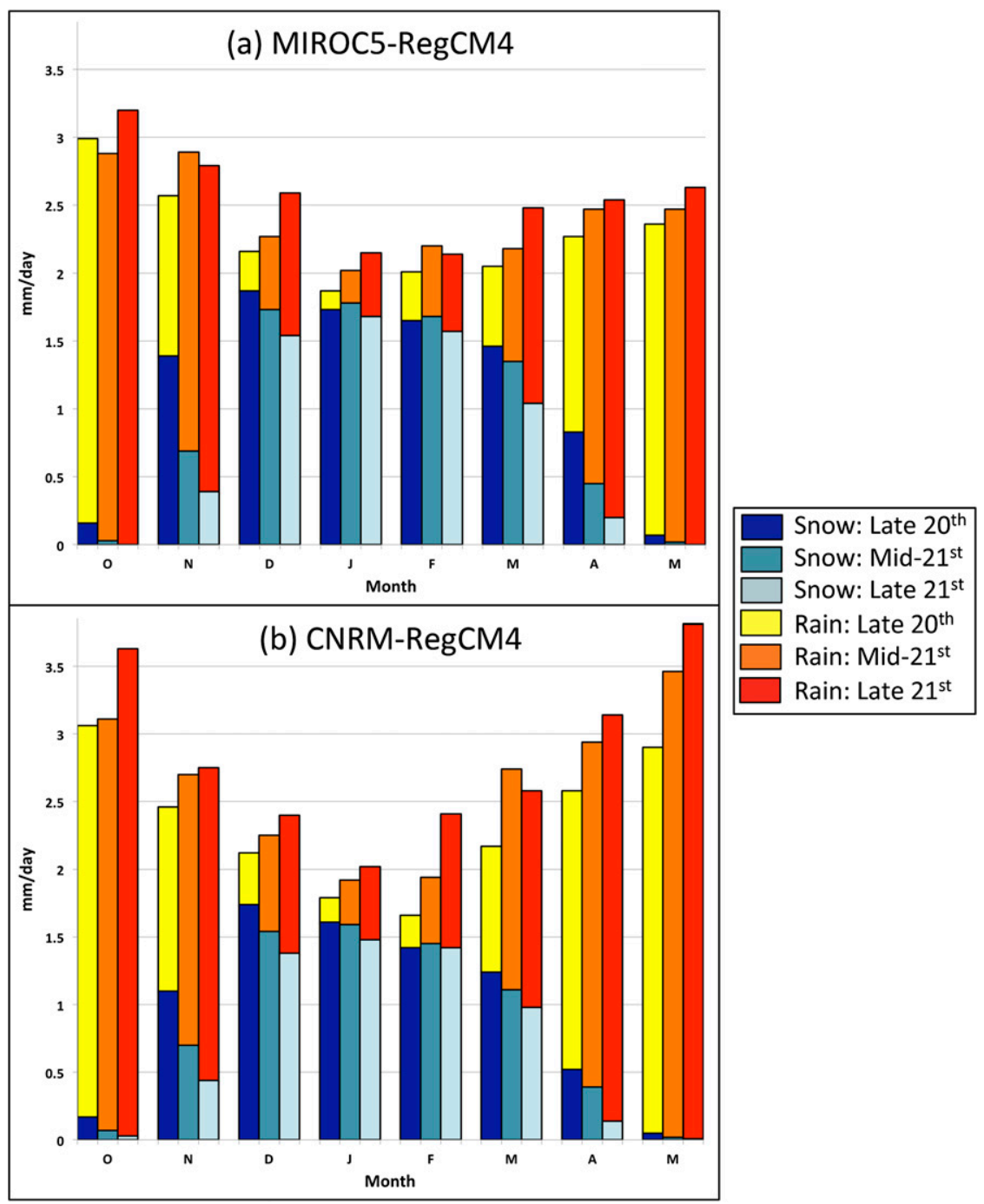

FIG. 16. Seasonal cycle (October-May) of the distribution of simulated mean total precipitation $\left(\mathrm{mm} \mathrm{day}^{-1}\right)$ as rain or snow in the Great Lakes basin (land only) for the late twentieth (1980-99), mid-twenty-first (2040-59), and late twenty-first (2080-99) centuries, according to (a) MIROC5-RegCM4 and (b) CNRM-RegCM4.

century indicate fewer heavy lake-effect snowstorms. Lake Superior is located in the coldest environment of the five lakes, allowing heavy lake-effect precipitation events in the mid-twenty-first century to often occur in the form of snow, despite significant warming. The projected occurrence of heavy lake-effect snowstorms becomes largely confined to January-March as further evidence of a future compressed snow season. Cold-season precipitation is projected to increase in the Great Lakes basin, with substantial increases in rainfall at the expense of snowfall, even in the case of lake-effect precipitation.

The mid-twenty-first century projections presented here are consistent with that of Gula and Peltier (2012). Their late twentieth century CCSM3-WRF simulations likewise exhibit an excessive ice cover bias, with Lake
Superior typically achieving $100 \%$ ice cover for over two months. By forcing FLake offline with the GCM output to generate lake LBCs for the RCM, their model setup potentially generates inconsistencies between imposed LSTs and lake ice and the RCM-generated climate. Their projections of atmospheric warming, diminished lake ice duration, earlier lake stratification, reduced annual snowfall, and localized increases in midwinter snowfall downwind of Lake Superior are largely in agreement with the present study's findings. The simulations by Gula and Peltier (2012) do not represent critical atmosphere-lake feedbacks, which can potentially amplify the impact of the lakes on regional climate. For example, in the present study, the albedo feedback likely accelerated the decline in lake ice cover, as 
atmospheric warming reduced ice cover and associated albedo, resulting in additional warming and further reduction in ice cover. The study by Kunkel et al. (2002) is consistent with the present study in that both project large reductions in the frequency of heavy lake-effect snowstorms by the end of the century, although the former study only examined Lake Erie.

Future research on lake-effect snow projections should explore the application of a nonhydrostatic RCM to addresses finer spatial scales and of a 3D lake model to represent the Great Lakes' circulation and reduce biases in LSTs, lake ice cover, and timing of stratification. In light of both natural variability and differences in greenhouse gas sensitivity and parameterizations among models, a wider pool of CMIP5 models needs to be downscaled to quantify the degree of uncertainty in projections, ideally run transiently through the twenty-first century to identify a potential reversal point in the sign of the lake-effect snow trend. Furthermore, the ecological and societal impacts of projected changes in heavy lake-effect snowstorms warrant further exploration.

Acknowledgments. This study was funded by grants and contracts from NOAA Climate Change Data and Detection, NOAA/Great Lakes Environmental Research Laboratory, and Michigan Department of Natural Resources (from Environmental Protection Agency funding). The authors appreciate the assistance of Drs. Graziano Guiliani, Nellie Elguindi, and Filippo Giorgi in aiding in the debugging and improvement of the 1D lake model. We acknowledge the World Climate Research Programme's Working Group on Coupled Modelling, which is responsible for CMIP, and we thank the climate modeling groups for producing and making available their model output. For CMIP, the U.S. Department of Energy's Program for Climate Model Diagnosis and Intercomparison provides coordinating support and led development of software infrastructure in partnership with the Global Organization for Earth System Science Portals. Gaugeadjusted precipitation data and lake vertical temperature profiles were provided by Jenny Adam and Dr. Brent Lofgren, respectively. Computational resources were provided through NCAR and the Teragrid from the University of Texas at Austin and the University of Illinois at Urbana-Champaign.

\section{REFERENCES}

Adam, J. C., and D. P. Lettenmaier, 2003: Adjustment of global gridded precipitation for systematic bias. J. Geophys. Res., 108, 4257, doi:10.1029/2002JD002499.

_ E. A. Clark, D. P. Lettenmaier, and E. F. Wood, 2006: Correction of global precipitation products for orographic effects. J. Climate, 19, 15-38, doi:10.1175/JCLI3604.1.
Anderson, C. J., R. W. Arritt, and J. S. Kain, 2007: An alternative mass flux profile in the Kain-Fritsch convective parameterization and its effects in seasonal precipitation. J. Hydrometeor., 8, 1128-1140, doi:10.1175/JHM624.1.

Anderson, E. A., 1976: A point energy and mass balance model of a snow cover. NOAA Tech. Rep. NWS 19,150 pp.

_ 2006: Snow accumulation and ablation model-SNOW 17. U.S. National Weather Service, Silver Spring, MD, 61 pp.

Antic, S., R. Laprise, B. Denis, and R. de Elía, 2004: Testing the downscaling ability of a one-way nested regional climate model in regions of complex topography. Climate Dyn., 23, 473-493, doi:10.1007/s00382-004-0438-5.

Assel, R. A., 1990: An ice-cover climatology for Lake Erie and Lake Superior for the winter seasons $1897-1898$ to $1982-1983$. Int. J. Climatol., 10, 731-748, doi:10.1002/joc.3370100707.

_- 2003: Great Lakes ice cover, first ice, last ice, and ice duration: Winters 1973-2002. NOAA Tech. Memo. GLERL-125, 49 pp. [Available online at http://www.glerl.noaa.gov/ftp/ publications/tech_reports/glerl-125/tm-125.pdf.]

— tures near Lake Michigan, 1851-1993, as determined from regional lake-ice records. Limnol. Oceanogr., 40, 165-176, doi:10.4319/lo.1995.40.1.0165.

Austin, J., and S. Colman, 2007: Lake Superior summer water temperatures are increasing more rapidly than regional air temperatures: A positive ice-albedo feedback. Geophys. Res. Lett., 34, L06604, doi:10.1029/2006GL029021.

Bader, D. C., and Coauthors, 2008: The added value of regional climate model simulations. Climate Models: An Assessment of Strengths and Limitations for User Applications, Climate Change Science Program, Department of Energy, 31-38.

Ballentine, R. J., A. J. Stamm, E. E. Chermack, G. P. Byrd, and D. Schleede, 1998: Mesoscale model simulation of the 4-5 January 1995 lake-effect snowstorm. Wea. Forecasting, 13, 893-920, doi:10.1175/1520-0434(1998)013<0893:MMSOTJ > 2.0.CO;2.

Bard, L., and D. A. R. Kristovich, 2012: Trend reversal in Lake Michigan contribution to snowfall. J. Appl. Meteor. Climatol., 51, 2038-2046, doi:10.1175/JAMC-D-12-064.1.

Bates, G. T., S. W. Hostetler, and F. Giorgi, 1995: Two-year simulation of the Great Lakes region with a coupled modeling system. Mon. Wea. Rev., 123, 1505-1522, doi:10.1175/ 1520-0493(1995)123<1505:TYSOTG>2.0.CO;2.

Bennington, V., G. A. McKinley, N. Kimura, and C. H. Wu, 2010: General circulation of Lake Superior: Mean, variability, and trends from 1979 to 2006. J. Geophys. Res., 115, C12015, doi:10.1029/2010JC006261.

— M. Notaro, and K. Holman, 2014: Improving climate sensitivity of deep lakes within a regional climate model and its impact on simulated climate. J. Climate, 27, 2886-2911, doi:10.1175/JCLI-D-13-00110.1.

Blumberg, A. F., and D. M. Di Toro, 1990: Effects of climate warming on dissolved oxygen concentrations in Lake Erie. Trans. Amer. Fish. Soc., 119, 210-223, doi:10.1577/ 1548-8659(1990)119<0210:EOCWOD>2.3.CO;2.

Burnett, A. W., M. E. Kirby, H. T. Mullins, and W. P. Patterson, 2003: Increasing Great Lake-effect snowfall during the twentieth century: A regional response to global warming? J. Climate, 16, 3535-3542, doi:10.1175/1520-0442(2003)016<3535: IGLSDT $>2.0 . \mathrm{CO} ; 2$.

Byerle, L. A., and J. Paegle, 2003: Modulation of the Great Plains low-level jet and moisture transports by orography and largescale circulations. J. Geophys. Res., 108, 8611, doi:10.1029/ 2002JD003005. 
Changnon, S. A., Jr., 1979: How a severe winter impacts on individuals. Bull. Amer. Meteor. Soc., 60, 110-114, doi:10.1175/ 1520-0477(1979)060<0110:HASWIO > 2.0.CO;2.

Cohen, S. J., and T. R. Allsopp, 1988: The potential impacts of a scenario of $\mathrm{CO}_{2}$-induced climatic change on Ontario, Canada. J. Climate, 1, 669-681, doi:10.1175/1520-0442(1988)001<0669: TPIOAS $>2.0 . \mathrm{CO} ; 2$.

Committee on Environment and Natural Resources, 2010: Scientific assessment of hypoxia in U.S. coastal waters. Interagency Working Group on Harmful Algal Blooms, Hypoxia, and $\mathrm{Hu}-$ man Health of the Joint Subcommittee on Ocean Science and Technology, 154 pp. [Available online at http://www.whitehouse. gov/sites/default/files/microsites/ostp/hypoxia-report.pdf.]

Denis, B., R. Laprise, D. Caya, and J. Côté, 2002: Downscaling ability of one-way nested regional climate models: The BigBrother Experiment. Climate Dyn., 18, 627-646, doi:10.1007/ s00382-001-0201-0.

Dewey, K. F., 1979: An objective forecast method developed for Lake Ontario induced snowfall systems. J. Appl. Meteor., 18, 787-793, doi:10.1175/1520-0450(1979)018<0787: $\mathrm{AOFMDF}>2.0 . \mathrm{CO} ; 2$

Diaz, R. J., and R. Rosenberg, 2008: Spreading dead zones and consequences for marine ecosystems. Science, 321, 926-929, doi:10.1126/science.1156401.

Dickinson, R. E., P. J. Kennedy, A. Henderson-Sellers, and M. Wilson, 1986: Biosphere-Atmosphere Transfer Scheme (BATS) for the NCAR Community Climate Model. NCAR Tech. Rep. NCAR/TN-275+STR, 69 pp, doi:10.5065/ D6668B58.

— A. Henderson-Sellers, and P. J. Kennedy, 1993: BiosphereAtmosphere Transfer Scheme (BATS) version 1e as coupled to the NCAR Community Climate Model. NCAR Tech. Note NCAR/TN-387+STR, 72 pp, doi:10.5065/D67W6959.

Eichenlaub, V. L., 1979: Weather and Climate of the Great Lakes Region. University of Notre Dame Press, $335 \mathrm{pp}$.

Elguindi, N., and Coauthors, 2011: Regional Climatic Mode RegCM User Manual version 4.1. The Abdus Salam International Centre for Theoretical Physics, $32 \mathrm{pp}$.

Ellis, A. W., and J. J. Johnson, 2004: Hydroclimatic analysis of snowfall trends associated with the North American Great Lakes. J. Hydrometeor., 5, 471-486, doi:10.1175/ 1525-7541(2004)005<0471:HAOSTA $>2.0 . \mathrm{CO} ; 2$.

Feser, F., B. Rockel, H. von Storch, J. Winterfeldt, and M. Zahn, 2011: Regional climate models add value to global model data: A review and selected examples. Bull. Amer. Meteor. Soc., 92, 1181-1192, doi:10.1175/2011BAMS3061.1.

Fritsch, J. M., and C. F. Chappell, 1980: Numerical prediction of convectively driven mesoscale pressure systems. Part I: Convective parameterization. J. Atmos. Sci., 37, 1722-1733, doi:10.1175/1520-0469(1980)037<1722:NPOCDM>2.0.CO;2.

Gerbush, M. R., D. A. R. Kristovich, and N. F. Laird, 2008: Mesoscale boundary layer and heat fluxes variations over pack ice-covered Lake Erie. J. Appl. Meteor. Climatol., 47, 668682, doi:10.1175/2007JAMC1479.1.

Giorgi, F., and Coauthors, 2012: RegCM4: Model description and preliminary tests over multiple CORDEX domains. Climate Res., 52, 7-29, doi:10.3354/cr01018.

Grell, G. A., 1993: Prognostic evaluation of assumptions used by cumulus parameterizations. Mon. Wea. Rev., 121, 764-787, doi:10.1175/1520-0493(1993)121<0764:PEOAUB > 2.0.CO;2.

_ J. Judhia, and D. R. Stauffer, 1994: Description of the fifth generation Penn State/NCAR Mesoscale Model (MM5). NCAR Tech. Rep. TN-398+STR, 121 pp.
Gula, J., and W. R. Peltier, 2012: Dynamical downscaling over the Great Lakes basin of North America using the WRF regional climate model: The impact of the Great Lakes system on regional greenhouse warming. J. Climate, 25, 7723-7742, doi:10.1175/JCLI-D-11-00388.1.

Hawley, N., and Coauthors, 2006: Lake Erie hypoxia prompts Canada-U.S. study. Eos, Trans. Amer. Geophys. Union, 87, 313-324, doi:10.1029/2006EO320001.

Hay, L. E., M. P. Clark, M. Pagowski, G. H. Leavesley, and W. J. Gutowski Jr., 2006: One-way coupling of an atmospheric and a hydrologic model in Colorado. J. Hydrometeor., 7, 569-589, doi:10.1175/JHM512.1.

Hill, J. D., 1971: Snow squalls in the lee of Lakes Erie and Ontario. NOAA Tech. Memo. NWS ER-43, 20 pp.

Hjelmfelt, M. R., and R. R. Braham Jr., 1983: Numerical simulation of the airflow over Lake Michigan for a major lake-effect snow event. Mon. Wea. Rev., 111, 205-219, doi:10.1175/ 1520-0493(1983)111<0205:NSOTAO $>2.0 . \mathrm{CO} ; 2$.

Holman, K. D., A. D. Gronewold, M. Notaro, and A. Zarrin, 2012: Improving historical precipitation estimates around the Lake Superior watershed. Geophys. Res. Lett., 39, L03405, doi:10.1029/2011GL050468.

Hostetler, S. W., 1991: Simulation of lake ice and its effect on the late-Pleistocene evaporation rate of Lake Lahontan. Climate Dyn., 6, 43-48, doi:10.1007/BF00210581.

— , and P. J. Bartlein, 1990: Simulation of lake evaporation with application to modeling lake-level variations at HarneyMalheur Lake, Oregon. Water Resour. Res., 26, 2603-2612, doi:10.1029/WR026i010p02603.

, G. T. Bates, and F. Giorgi, 1993: Interactive coupling of a lake thermal model with a regional climate model. J. Geophys. Res., 98, 5045-5057, doi:10.1029/92JD02843.

Jones, R. G., J. M. Murphy, and M. Noguer, 1995: Simulation of climate change over Europe using a nested regional-climate model. I: Assessment of control climate, including sensitivity to location of lateral boundaries. Quart. J. Roy. Meteor. Soc., 121, 1413-1449, doi:10.1002/qj.49712152610.

Kalnay, E., and Coauthors, 1996: The NCEP/NCAR 40-Year Reanalysis Project. Bull. Amer. Meteor. Soc., 77, 437-471, doi:10.1175/1520-0477(1996)077<0437:TNYRP>2.0.CO;2.

Kanamitsu, M., and L. DeHaan, 2011: The added value index: A new metric to quantify the added value of regional models. J. Geophys. Res., 116, D11106, doi:10.1029/2011JD015597.

Kunkel, K. E., N. E. Westcott, and D. A. R. Kristovich, 2002: Assessment of potential effects of climate change on heavy lakeeffect snowstorms near Lake Erie. J. Great Lakes Res., 28, 521-536, doi:10.1016/S0380-1330(02)70603-5.

, L. Ensor, M. Palecki, D. Easterling, D. Robinson, K. G. Hubbard, and K. Redmond, 2009: A new look at lake-effect snowfall trends in the Laurentian Great Lakes using a temporally homogeneous data set. J. Great Lakes Res., 35, 23-29, doi:10.1016/j.jglr.2008.11.003.

Leung, L. R., and M. S. Wigmosta, 1999: Potential climate change impacts on mountain watersheds in the Pacific Northwest. J. Amer. Water Resour. Assoc., 35, 1463-1471, doi:10.1111/ j.1752-1688.1999.tb04230.x.

Li, Z., M. J. McCormick, D. Schwab, and S. A. Ruberg, 2009: Lake Michigan vertical temperature data midlake 1991-2007. NOAA Tech. Memo. ERL GLERL-09, 35 pp.

Liu, A. Q., and G. W. K. Moore, 2004: Lake-effect snowstorms over southern Ontario, Canada, and their associated synoptic-scale environment. Mon. Wea. Rev., 132, 2595-2609, doi:10.1175/ MWR2796.1. 
Martynov, A., K. Sushama, and R. Laprise, 2010: Simulation of temperate freezing lakes by one-dimensional lake models: Performance assessment for interactive coupling with regional climate models. Boreal Environ. Res., 15, 143-164.

Mearns, L. O., 2003: Issues in the impacts of climate variability and change on agriculture-Applications to the southeastern United States. Climatic Change, 60, 1-6, doi:10.1023/A:1026077531798.

_, F. Giorgi, L. McDaniel, and C. Shields, 2003: Climate scenarios for the southeastern US based on GCM and regional model simulations. Climatic Change, 60, 7-35, doi:10.1023/ A:1026033732707.

Mo, K. C., J.-K. Schemm, H. Juang, and R. W. Higgins, 2005: Impact of model resolution on the prediction of summer precipitation over the United States and Mexico. J. Climate, 18, 3910-3927, doi:10.1175/JCLI3513.1.

Niziol, T. A., W. R. Snyder, and J. S. Waldstricher, 1995: Winter weather forecasting throughout the eastern United States. Part IV: Lake effect snow. Wea. Forecasting, 10, 61-77, doi:10.1175/1520-0434(1995)010<0061:WWFTTE >2.0.CO;2.

Norton, D. C., and S. J. Bolsenga, 1993: Spatiotemporal trends in lake effect and continental snowfall in the Laurentian Great Lakes, 1951-1980. J. Climate, 6, 1943-1956, doi:10.1175/ 1520-0442(1993)006<1943:STILEA > 2.0.CO;2.

Notaro, M., K. Holman, A. Zarrin, S. Vavrus, and V. Bennington, 2013a: Influence of the Laurentian Great Lakes on regional climate. J. Climate, 26, 789-804, doi:10.1175/JCLI-D-12-00140.1.

_ A. Zarrin, S. Vavrus, and V. Bennington, 2013b: Simulation of heavy lake-effect snowstorms across the Great Lakes basin by RegCM4: Synoptic climatology and variability. Mon. Wea. Rev., 141, 1990-2014, doi:10.1175/MWR-D-11-00369.1.

— D. Lorenz, C. Hoving, and M. Schummer, 2014: Twenty-firstcentury projections of snowfall and winter severity across central-eastern North America. J. Climate, 27, 6526-6550, doi:10.1175/JCLI-D-13-00520.1.

Orlanski, I., 1975: A rational subdivision of scales for atmospheric processes. Bull. Amer. Meteor. Soc., 56, 527-530.

Pal, J. S., E. E. Small, and E. A. B. Eltahir, 2000: Simulation of regionalscale water and energy budgets: Representation of subgrid cloud and precipitation processes within RegCM. J. Geophys. Res., 105, 29579-29594, doi:10.1029/2000JD900415.

Patterson, J. C., and P. F. Hamblin, 1988: Thermal simulation of a lake with winter ice cover. Limnol. Oceanogr., 33, 323-338, doi:10.4319/lo.1988.33.3.0323.

Rayner, N. A., E. B. Horton, D. E. Parker, C. K. Folland, and R. B. Hackett, 1996: Version 2.2 of the global sea ice and sea surface temperature data set, 1903-1994. Hadley Centre Climate
Research Tech. Note CRTN74, 35 pp. [Available online at hadobs.metoffice.com/gisst/crtn74.pdf.]

Roads, J. O., S.-C. Chen, and M. Kanamitsu, 2003: U.S. regional climate simulations and seasonal forecasts. J. Geophys. Res., 108, 8606, doi:10.1029/2002JD002232.

Schmidlin, T. W., 1993: Impacts on severe winter weather during December 1989 in the Lake Erie snowbelt. J. Climate, 6, 759-767, doi:10.1175/1520-0442(1993)006<0759:IOSWWD>2.0.CO;2.

Schwab, D., G. Leshkevich, and G. Muhr, 1992: Satellite measurements of surface water temperature in the Great Lakes: Great Lakes Coastwatch. J. Great Lakes Res., 18, 247-258, doi:10.1016/S0380-1330(92)71292-1.

Sousounis, P. J., and J. M. Fritsch, 1994: Lake-aggregate mesoscale disturbances. Part II: A case study of the effects of regional and synoptic-scale weather systems. Bull. Amer. Meteor. Soc., 75, 1793-1811, doi:10.1175/1520-0477(1994)075<1793: LAMDPI $>2.0 . \mathrm{CO} ; 2$.

Takata, K., S. Emori, and T. Watanabe, 2003: Development of the minimal advanced treatments of surface interaction and runoff. Global Planet. Change, 38, 209-222, doi:10.1016/ S0921-8181(03)00030-4.

Taylor, K. E., R. J. Stouffer, and G. A. Meehl, 2012: An overview of CMIP5 and the experiment design. Bull. Amer. Meteor. Soc., 93, 485-498, doi:10.1175/BAMS-D-11-00094.1.

Vavrus, S., J. E. Walsh, W. L. Chapman, and D. Portis, 2006: The behavior of extreme cold air outbreaks under greenhouse warming. Int. J. Climatol., 26, 1133-1147, doi:10.1002/joc.1301.

_- M. Notaro, and A. Zarrin, 2013: The role of ice cover in heavy lake-effect snowstorms over the Great Lakes basin as simulated by RegCM4. Mon. Wea. Rev., 141, 148-165, doi:10.1175/ MWR-D-12-00107.1.

Voldoire, A., and Coauthors, 2013: The CNRM-CM5.1 global climate model: Description and basic evaluation. Climate Dyn., 40, 2091-2121, doi:10.1007/s00382-011-1259-y.

Warner, T. T., and N. L. Seaman, 1990: A real-time, mesoscale numerical weather prediction system used for research, teaching, and public service at the Pennsylvania State University. Bull. Amer. Meteor. Soc., 71, 792-805, doi:10.1175/ 1520-0477(1990)071<0792:ARTMNW>2.0.CO;2.

Watanabe, M., and Coauthors, 2010: Improved climate simulation by MIROC5: Mean states, variability, and climate sensitivity. J. Climate, 23, 6312-6335, doi:10.1175/2010JCLI3679.1.

Willmott, C. J., and K. Matsuura, cited 2000: Terrestrial air temperature and precipitation: Monthly and annual time series (1950-1996) (version 1.01). [Available online at http://climate. geog.udel.edu/ climate/html_pages/download.html.] 